Received: 15 March 2017

Accepted: 1 September 2017

Published online: 12 October 2017

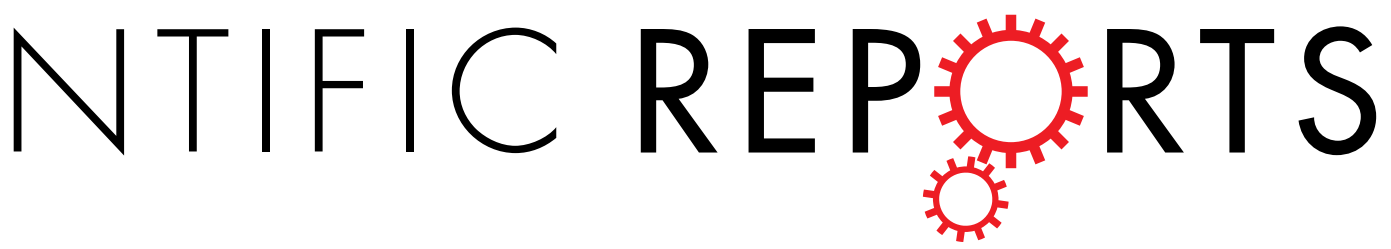

\title{
Translesion synthesis DNA polymerase $\eta$ exhibits a specific RNA extension activity and a transcription-associated function
}

Vamsi K. Gali ${ }^{1,3}$, Eva Balint $\mathbb{D}^{1}$, Nataliia Serbyn ${ }^{2}$, Orsolya Frittmann ${ }^{1}$, Francoise Stutz ${ }^{2}$ \& Ildiko Unk ${ }^{1}$

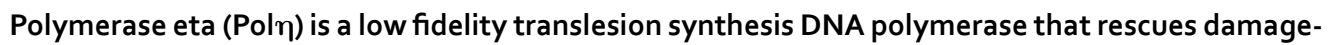
stalled replication by inserting deoxy-ribonucleotides opposite DNA damage sites resulting in errorfree or mutagenic damage bypass. In this study we identify a new specific RNA extension activity of Pol $\eta$ of Saccharomyces cerevisiae. We show that Pol $\eta$ is able to extend RNA primers in the presence of ribonucleotides (rNTPs), and that these reactions are an order of magnitude more efficient than the misinsertion of rNTPs into DNA. Moreover, during RNA extension Poln performs error-free bypass of the 8-oxoguanine and thymine dimer DNA lesions, though with a $10^{3}$ and $10^{2}$-fold lower efficiency, respectively, than it synthesizes opposite undamaged nucleotides. Furthermore, in vivo experiments demonstrate that the transcription of several genes is affected by the lack of Pol $\eta$, and that Pol $\eta$ is enriched over actively transcribed regions. Moreover, inactivation of its polymerase activity causes similar transcription inhibition as the absence of Poln. In summary, these results suggest that the new RNA synthetic activity of Poln can have in vivo relevance.

When DNA replication is blocked by DNA lesions, DNA damage tolerance (DDT) mechanisms are activated that can sustain replication on damaged templates without removing the damage. One mechanism of DDT is translesion synthesis (TLS), where specialized DNA polymerases synthesize across the damage and/or extend from it $^{1}$. TLS polymerases can be found in all three domains of life. They display lowered selectivity and fidelity compared to replicative polymerases due to their large active center and to their lack of a proofreading activity. Their non-selective active center can accommodate damaged and modified bases enabling them to perform TLS. Damage bypass can be error-free or error-prone depending on whether the correct or an incorrect nucleotide is inserted opposite a lesion. Error-free bypass contributes to genomic stability, whereas error-prone damage bypass increases instability by causing mutagenesis. The RAD30-encoded TLS DNA polymerase Pol $\eta$ of Saccharomyces cerevisiae can bypass several DNA lesions in a faithful or mutagenic manner. It stands out among other polymerases by its unique ability to efficiently and accurately bypass cyclobutane pyrimidine dimers (CPDs), the most frequent UV-induced DNA lesions ${ }^{2}$. It can do so because its active center can accommodate both nucleotides of the dimer ${ }^{3}$. Pol $\eta$ can also bypass efficiently and error-freely 8-oxoguanine (8-oxoG), one of the most abundant spontaneous oxidative lesions, whereas replicative DNA polymerases carry out mostly error-prone bypass of this damage ${ }^{4}$. Though Pol $\eta$ is highly error-prone on non-damaged DNA, its inactivation in yeast cells and in mouse cell lines increases the UV-induced mutation rate ${ }^{5-7}$, while in humans it causes a cancer-prone syndrome, the variant form of xeroderma pigmentosum ${ }^{8,9}$. These findings indicate that the main in vivo function of Pol $\eta$ is non-mutagenic and its activity is mostly restricted to damage sites. The distributive mode of DNA synthesis by Pol $\eta$, that dissociates from DNA after inserting only a few nucleotides, probably also serves to confine its activity $^{10}$. Pol $\eta$ can get access to the stalled replication fork through its interaction with proliferating cell nuclear antigen (PCNA), the processivity clamp of the replicative DNA polymerases ${ }^{11,12}$. The interaction with PCNA is

\footnotetext{
${ }^{1}$ The Institute of Genetics, Biological Research Centre, Hungarian Academy of Sciences, Szeged, H-6726, Hungary. ${ }^{2}$ Department of Cell Biology, iGE3, University of Geneva, 1211, Geneva, Switzerland. ${ }^{3}$ Present address: Institute of Medical Sciences Foresterhill, University of Aberdeen, Aberdeen, United Kingdom. Vamsi K. Gali and Eva Balint contributed equally to this work. Correspondence and requests for materials should be addressed to I.U. (email: unk. ildiko@brc.mta.hu)
} 
essential for the in vivo function of Pol $\eta$, as mutations disrupting this interaction cause the same phenotype in yeast as the complete lack of Pol $\eta^{11}$.

DNA polymerases use deoxy-ribonucleotides (dNTPs) when synthesizing DNA, despite the much higher cellular concentration of ribonucleotides (rNTPs). It was discovered that a specific amino acid, called the "steric gate", is responsible for exclusion of rNTPs from the active site of DNA polymerases ${ }^{13-15}$. However, the exclusion is not complete and even the major replicative DNA polymerases have been shown to insert rNTPs during DNA synthesis with varying low frequency ${ }^{16-20}$. The presence of ribonucleotides in the genome is destabilizing ${ }^{21}$, and is counteracted by ribonucleotide excision repair that efficiently removes ribonucleotides from the genomic DNA ${ }^{22}$.

In this study we show that Pol $\eta$ is inefficient in inserting rNTPs during DNA synthesis, but unexpectedly, it has the specific activity to extend RNA strands with ribonucleotides. Moreover, Pol $\eta$ can mediate RNA TLS during RNA extension with the same fidelity as it does during DNA synthesis, although with very low efficiencies. Pol $\eta$ can also insert dNTPs into RNA, and it does so with similar efficiencies as with rNTPs at nucleotide concentrations estimating the in vivo conditions. Moreover, damage bypass by Pol $\eta$ is more efficient with dNTPs during RNA extension. Nevertheless, Pol $\eta$ is required for the efficient transcription of several genes in vivo and is physically associated with the open reading frame of the actively transcribed GAL1 gene. Furthermore, we demonstrate that the polymerase activity of Pol $\eta$ is required for its transcription-associated function in vivo. Based on our findings we propose a role for the discovered new RNA synthetic activity of Pol $\eta$ during transcription.

\section{Results}

Pol $\eta$ has the specific activity to extend RNA strands with ribonucleotides. We examined whether Pol $\eta$ could use rNTPs when synthesizing DNA, by performing in vitro primer extension assays in the presence of purified recombinant Pol $\eta$ (Fig. 1a). The activity of Pol $\eta$ was confirmed in control DNA extension reactions in the presence of dNTPs (Fig. 1b). When rNTPs were added to the reactions instead of dNTPs, Pol $\eta$ was still able to extend the DNA primer using ribonucleotides (Fig. 1b). Although this extension was very inefficient and required high enzyme concentrations, Pol $\eta$ could synthesize a ribonucleotide chain on the DNA primer using rNTPs, as indicated by the appearance of lower mobility bands on the gel. Thus, the terminal ribonucleotide did not inhibit further synthesis and Pol $\eta$ was able to extend not only a terminal deoxy-ribonucleotide, but also a terminal ribonucleotide containing primer. This prompted us to investigate the ribonucleotide chain extension ability of Pol $\eta$ in reactions containing a DNA template hybridized with an RNA primer in the presence of rNTPs. Importantly, these experiments demonstrated that Pol $\eta$ was able to extend an RNA primer with rNTPs and to catalyze the formation of a polyribonucleotide chain (Fig. 1c). The absence of any polymerase activity when using the catalytically inactive Pol $\eta$ D30A mutant in these assays confirmed that both the DNA and RNA synthetic activities are intrinsic to Pol $\eta$ (Fig. 1d). Notably, the extension of a primer with dNTPs or rNTPs results in slightly different electrophoretic mobility; it can therefore be ruled out that the observed activity results from contamination of the rNTPs by dNTPs (Fig. 1b last two rows, and Fig. S2).

Pol $\eta$ seemed rather inefficient in RNA extension with rNTPs as opposed to DNA extension with dNTPs. For example, at $11 \mathrm{nM}$ enzyme concentration Pol $\eta$ extended nearly all the DNA primers in the reaction with dNTPs, whereas almost no insertion of rNTPs into RNA could be observed at the same enzyme concentration (compare Fig. $1 \mathrm{~b}$ and c). However, the applied $100 \mu \mathrm{M}$ dNTP concentration was much higher than the intracellular dNTP level that ranges from 12-30 $\mu \mathrm{M}$, and vice versa, the applied $100 \mu \mathrm{M}$ rNTP concentration was much lower than the intracellular rNTP level of $0.5-3 \mathrm{mM}^{16}$. To clarify whether the RNA extension ability of Pol $\eta$ reflected a specific activity or was the result of misinsertion, we performed steady-state kinetic analysis where we compared the efficiency of rNTP incorporation by Pol $\eta$ into RNA versus DNA. Remarkably, Pol $\eta$ extended RNA primers with rNTPs an order of magnitude more efficiently than DNA primers, except in the case of rATP (Fig. 2 compare a to $\mathbf{e}, \mathbf{b}$ to $\mathbf{f}, \mathbf{c}$ to $\mathbf{g}$, and $\mathbf{d}$ to $\mathbf{h}$; Tables 1 and 2). For example, Pol $\eta$ incorporated rGTP into RNA $\sim 30$, and rCTP $\sim 20$ times more efficiently than into DNA, whereas rUTP incorporation into DNA was so weak that it was not measurable (Fig. 2h). Significantly, the $K_{m}$ values for RNA extension with single rNTPs were in the range of the intracellular concentrations of rNTPs suggesting that the activity might have an in vivo relevance. In summary, these results show that Pol $\eta$ recognizes RNA as its substrate and that rNTP incorporation into RNA is specific and not merely misincorporation due to the not-so-stringent active center of Pol $\eta$.

Poln can extend RNA with deoxy-ribonucleotides. Next we investigated whether Pol $\eta$ selectively inserted rNTPs during RNA synthesis, or whether dNTP misinsertion could also occur. For this reason we applied single dNTPs in the RNA primer extension reactions and determined the kinetic parameters of the reactions (Fig. 3 and Table 3). As our steady-state kinetic assays showed, the $K_{c a t} / K_{m}$ values for dNTP insertions were much higher compared to rNTP insertions indicating that dNTP insertions were more effective. However, when we took into consideration the big difference between the in vivo concentrations of dNTPs and rNTPs, the relative frequencies were around 1 (Table 3 ) meaning that at physiological dNTP and rNTP concentrations Pol $\eta$ inserts dNTPs and rNTPs into RNA with similar efficiencies.

Pol $\eta$ can perform error-free bypass of an 8-oxoG and a TT dimer during RNA extension. The main identified cellular function of Pol $\eta$ is to promote DNA replication through DNA damages by inserting dNTPs opposite to damage sites. To test whether it exhibits similar activity during RNA extension, we examined Pol $\eta$ damage bypass ability in vitro using an 8-oxoG, or a TT dimer containing oligonucleotide. We chose these DNA lesions because Pol $\eta$ was already shown to bypass them efficiently and in an error free manner during DNA synthesis ${ }^{2,4}$. We confirmed that Pol $\eta$ can bypass these DNA lesions during DNA synthesis with dNTPs (Fig. 4a and f). Furthermore, Pol $\eta$ was able to extend the RNA primer opposite an 8-oxoG (Fig. 4b) and a TT dimer (Fig. 4g) with rNTPs. More importantly, even when high $4 \mathrm{mM}$ single rNTP concentrations were included in the reactions, it inserted only CTP opposite 8-oxoG (Fig. 4c) and only ATP opposite the TT dimer (Fig. 4h). 


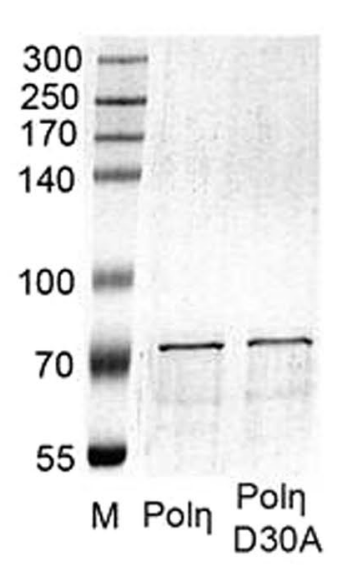

b
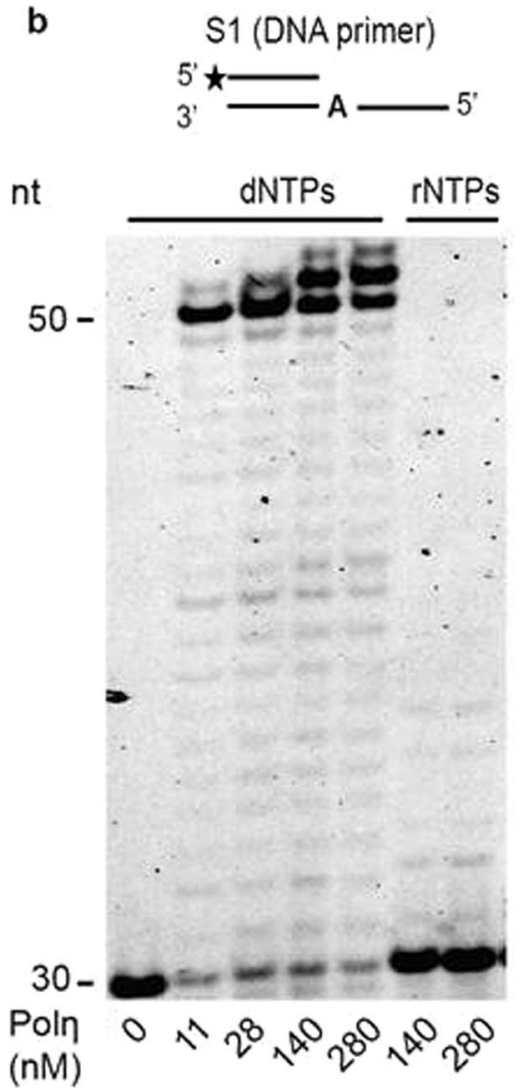

C S5 (RNA primer) rNTPS
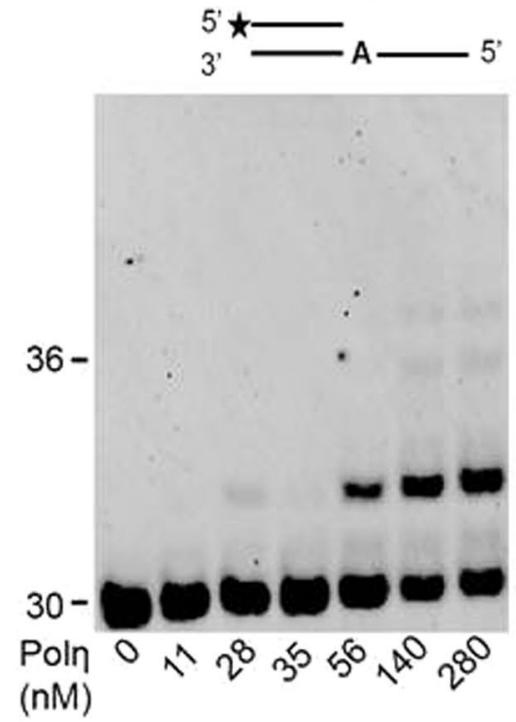

d

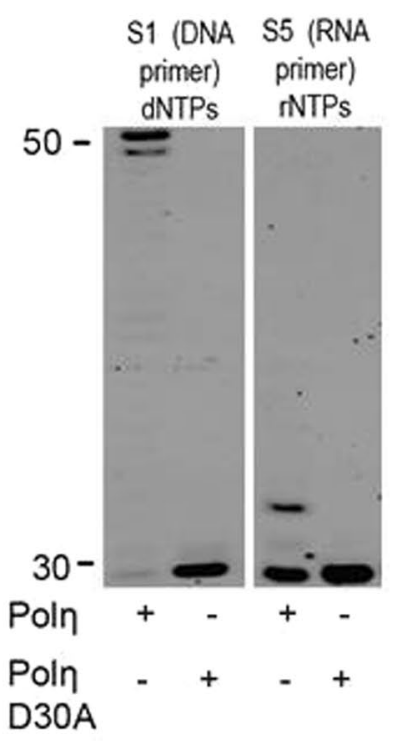

Figure 1. Pol $\eta$ can catalyze DNA and RNA extension with rNTPs. (a) Purity of recombinant Pol $\eta$ and Pol $\eta$ D30A. 200 ng of each protein was analyzed on $8 \%$ denaturing SDS-polyacrylamide gel. Molecular mass standards are shown on the left. (b) Pol $\eta$ can perform DNA primer extension with dNTPs and rNTPs. Reactions were carried out using $24 \mathrm{nM}$ template and increasing concentrations of Pol $\eta$, as indicated at the bottom, in the presence of $100 \mu \mathrm{M}$ dNTP or rNTP for $5 \mathrm{~min}$. (c) Pol $\eta$ can catalyze RNA primer extension with ribonucleotides. Reactions contained $16 \mathrm{nM}$ template and $100 \mu \mathrm{M} \mathrm{rNTP}$ and were incubated for $10 \mathrm{~min}$. (d) Pol $\eta$ D30A is defective in both DNA and RNA primer extensions. Reactions were incubated with wild-type or mutant Pol $\eta(140 \mathrm{nM})$, in the presence of $100 \mu \mathrm{M}$ of either dNTPs (left panel) or rNTPs (right panel) for $10 \mathrm{~min}$. The structures of the substrates are shown at the top of each panel. Asterisks mark the $5^{\prime} \mathrm{Cy} 3$ labeled ends. See Fig. 1 for full-length images. 
(a)
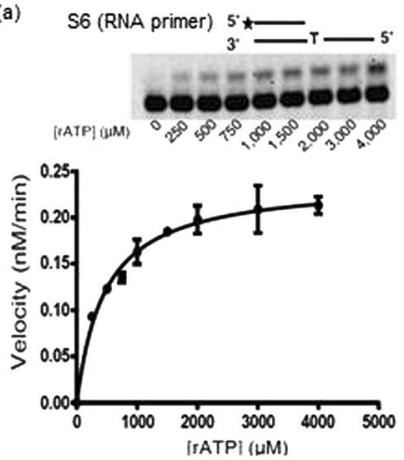

(b)
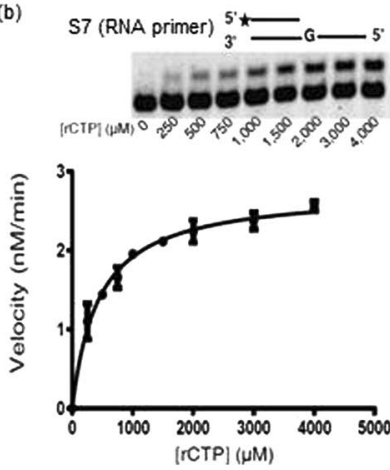

(c)

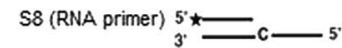

- -
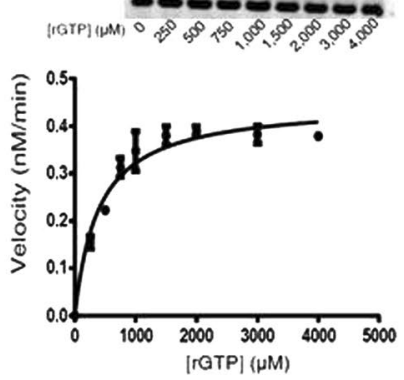

(d)

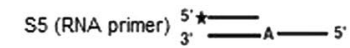

$0+\infty \operatorname{cosec0}$ [nUTP] (IM) 0 \&

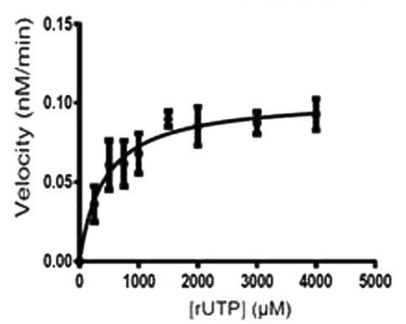

(e)
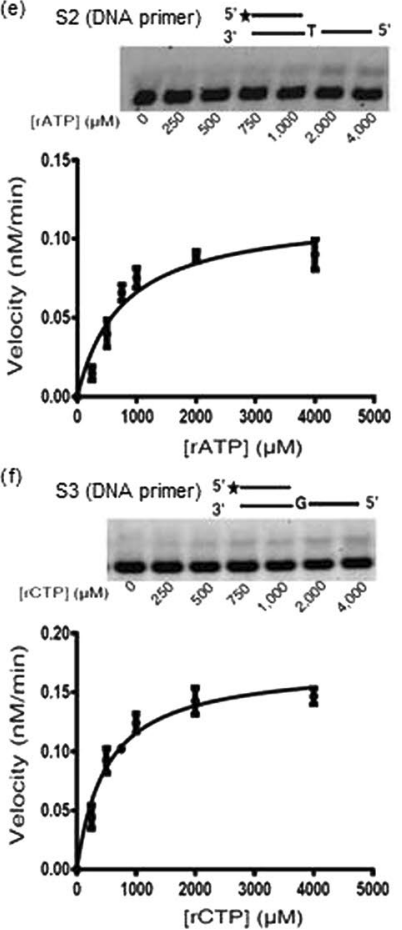

(g)
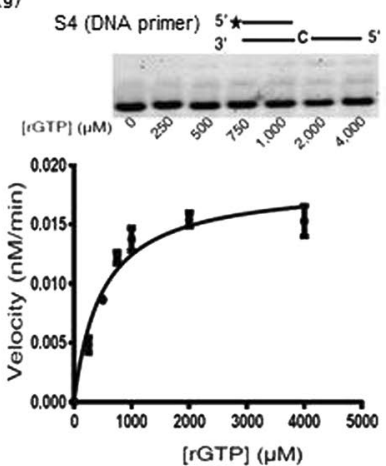

(h)

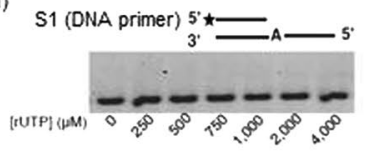

Figure 2. Steady-state kinetic analysis of RNA and DNA primer extensions with rNTPs by Pol $\eta$. RNA primer extension with (a) rATP, (b) rCTP, (c) rGTP, (d) rUTP is shown on the left. DNA primer extension with (e) rATP, (f) rCTP, (g) rGTP, (h) rUTP is shown on the right. Pol $\eta(1 \mathrm{nM})$ was incubated with $20 \mathrm{nM}$ of the indicated templates in the presence of increasing concentrations of the single incoming rNTP, as shown under the gel pictures. The quenched samples were analyzed by denaturing polyacrylamide gel electrophoresis, and quantified as described (see Materials and Methods). For each rNTP the rate of incorporation is plotted as a function of rNTP concentrations. The data were fit to the Michaelis-Menten equation (see Materials and Methods). In panel (h) incorporation of rUTP was so weak that it could not be quantified. See Fig. S3 for fulllength images. 


\begin{tabular}{|c|c|}
\hline Substrate & Sequence \\
\hline $\mathrm{S} 1$ & $\begin{array}{l}\text { /5Cy3/CGCTACCTAGCCTGCCTCAAGAGTTGCTCG } \\
\text { 3'-GCGATGGATCGGACGGAGTTCTCAACGAGCACAGGCTTACGCTCAGGTCG-5' }\end{array}$ \\
\hline S2 & $\begin{array}{l}\text { /5Cy3/CGCTACCTAGCCTGCCTCAAGAGTTGCTCG } \\
\text { 3'-GCGATGGATCGGACGGAGTTCTCAACGAGCTCAGGCTTACGCTCAGGTCG-5' }\end{array}$ \\
\hline S3 & $\begin{array}{l}\text { /5Cy3/CGCTACCTAGCCTGCCTCAAGAGTTGCTCG } \\
\text { 3'-GCGATGGATCGGACGGAGTTCTCAACGAGCGCAGGCTTACGCTCAGGTCG-5' }\end{array}$ \\
\hline S4 & $\begin{array}{l}\text { /5Cy3/CGCTACCTAGCCTGCCTCAAGAGTTGCTCG } \\
\text { 3'-GCGATGGATCGGACGGAGTTCTCAACGAGCCCAGGCTTACGCTCAGGTCG-5' }\end{array}$ \\
\hline S5 & $\begin{array}{l}\text { 15Cy3/CGCUACCUAGCCUGCCUCAAGAGUUGCUCG } \\
\text { 3'-GCGATGGATCGGACGGAGTTCTCAACGAGCACAGGCTTACGCTCAGGTCG-5' }\end{array}$ \\
\hline S6 & $\begin{array}{l}\text { 15Cy3/CGCUACCUAGCCUGCCUCAAGAGUUGCUCG } \\
\text { 3'-GCGATGGATCGGACGGAGTTCTCAACGAGCTCAGGCTTACGCTCAGGTCG-5' }\end{array}$ \\
\hline S7 & $\begin{array}{l}\text { /5Cy3/CGCUACCUAGCCUGCCUCAAGAGUUGCUCG } \\
\text { 3'-GCGATGGATCGGACGGAGTTCTCAACGAGCGCAGGCTTACGCTCAGGTCG-5' }\end{array}$ \\
\hline S8 & $\begin{array}{l}\text { /5Cy3/CGCUACCUAGCCUGCCUCAAGAGUUGCUCG } \\
\text { 3'-GCGATGGATCGGACGGAGTTCTCAACGAGCCCAGGCTTACGCTCAGGTCG-5' }\end{array}$ \\
\hline S9 & $\begin{array}{c}\text { /5Cy3/CGACGATGCTCCGGTACTCCAGTGTAGGCAT } \\
\text { 3’-AAAGGGTCAGTGCTGCTACGAGGCCATGAGGTCACATCCGTAGAATGCTTAAGAA CTCCGTCCGTACCATCGA-5' }\end{array}$ \\
\hline S10 & $\begin{array}{c}\text { /5Cy3/CGACGATGCTCCGGTACTCCAGTGTAGGCAT } \\
\text { 3’-AAAGGGTCAGTGCTGCTACGAGGCCATGAGGTCACATCCGTAGAATGCTTAAGAA CTCCGTCCGTACCATCGA-5' }\end{array}$ \\
\hline S11 & $\begin{array}{l}\text { /5Cy3/CGACGAUGCUCCGGUACUCCAGUGUAGGCAU } \\
\text { 3'-CAAAAGGGTCAGTGCTGCTACGAGGCCATGAGGTCACATCCGTAGAATGCTTAAGAA CTCCGTCCGTACCATCGA-5' }\end{array}$ \\
\hline $\mathrm{S} 12$ & $\begin{array}{l}\text { /5Cy3/CGACGAUGCUCCGGUACUCCAGUGUAGGCAU } \\
\text { 3'-CAAAAGGGTCAGTGCTGCTACGAGGCCATGAGGTCACATCCGTA }{ }^{\circ} \text { GAATGCTTAAGAA CTCCGTCCGTACCATCGA-5' }\end{array}$ \\
\hline S13 & $\begin{array}{l}\text { 15Cy3/CGTATTCGCGCGC } \\
\text { 3'-CGAATGGCGGTGCGTTGCGCGCGAATACG-5' }\end{array}$ \\
\hline S14 & $\begin{array}{l}\text { /5Cy3/CGTATTCGCGCGC } \\
\text { 3'-CGAATGGCGGTGCGT^TGCGCGCGAATACG-5' }\end{array}$ \\
\hline S15 & $\begin{array}{l}\text { /5Cy3/CGUAUUCGCGCGC } \\
\text { 3'-CGAATGGCGGTGCGTTGCGCGCGAATACG-5' }\end{array}$ \\
\hline S16 & $\begin{array}{l}\text { /5Cy3/CGUAUUCGCGCGC } \\
3^{\prime} \text {-CGAATGGCGGTGCGT^TAGCGCGCGAATACG-5' }\end{array}$ \\
\hline
\end{tabular}

Table 1. Sequence and structure of substrates used in the in vitro primer extension assays. RNA primers are underlined. The Cy3 label at the $5^{\prime}$ end of primers is indicated. The first templating nucleotides are in bold.

\begin{tabular}{|l|l|l|l|l|l|l|}
\hline Primer & $\begin{array}{l}\text { Insertion } \\
\text { opposite }\end{array}$ & $\begin{array}{l}\text { Incoming } \\
\text { riboucleotide }\end{array}$ & Kcat $(\mathbf{m i n}-\mathbf{1})$ & $\mathbf{K m}(\boldsymbol{\mu M})$ & $\mathbf{K c a t / K m}$ & $\begin{array}{l}\text { Relative } \\
\text { efficiency }\end{array}$ \\
\hline RNA & T & ATP & $0.2394 \pm 0.0065$ & $466.4 \pm 47.29$ & $5.13 \mathrm{E}-04$ & 3.34 \\
\hline RNA & G & CTP & $2.758 \pm 0.06217$ & $438.3 \pm 37.52$ & $62.9 \mathrm{E}-04$ & 18.26 \\
\hline RNA & C & GTP & $0.4487 \pm 0.01485$ & $393.7 \pm 52.04$ & $11.4 \mathrm{E}-04$ & 30.24 \\
\hline RNA & A & UTP & $0.1032 \pm 0.005715$ & $423.3 \pm 90.45$ & $2.43 \mathrm{E}-04$ & n.d \\
\hline DNA & T & ATP & $0.1163 \pm 0.009014$ & $757.6 \pm 160$ & $1.53 \mathrm{E}-04$ & \\
\hline DNA & G & CTP & $0.1733 \pm 0.007439$ & $503.1 \pm 68.83$ & $3.44 \mathrm{E}-04$ & \\
\hline DNA & C & GTP & $0.01851 \pm 0.000891$ & $491.2 \pm 76.14$ & $0.37 \mathrm{E}-04$ & \\
\hline DNA & A & UTP & - & - & - & \\
\hline
\end{tabular}

Table 2. Kinetic parameters of rNTP incorporation into DNA and RNA by Pol $\eta$. Values were obtained from results shown in Fig. 2, and represent the mean and standard error of three experiments. Kinetic parameters were calculated as described in "Materials and Methods". n.d, not determined (no insertion of UTP into DNA could be detected). Relative efficiency was calculated using the following equation: $f_{\text {ext }}=\left(k_{\text {cat }} / K_{m}\right)_{\mathrm{RNA}} /\left(k_{\text {cat }} /\right.$ $\left.K_{m}\right)_{\text {DNA }}$.

The result showing 2 rNTP insertions opposite 8-oxoG, but only 1 opposite the undamaged C (Fig. $4 \mathrm{~b}$ ) is in good agreement with the observation that Pol $\eta$ is more processive on damaged DNA ${ }^{23}$. The weak intensity of the bands in Fig. $4 \mathrm{~g}$ corresponding to multiple insertions is probably due to the applied lower enzyme/template ratio. In summary, these results show that Pol $\eta$ bypasses 8-oxoG and TT dimer in an error-free manner during RNA synthesis by inserting only the corresponding correct rNTPs opposite the lesions.

Pol $\eta$ can bypass DNA damage with dNTPs during RNA extension. Next we checked the efficiencies of the bypass reactions by kinetic analysis applying the single correct incoming rNTPs (Fig. $4 \mathrm{~d}$ and i, and Fig. S6). For both 8-oxoG and TT dimer bypass we obtained very low $\mathrm{K}_{\mathrm{cat}} / \mathrm{K}_{\mathrm{m}}$ values, 1000 times and 100 times lower numbers than measured on undamaged templates, respectively, reflecting the inefficient nature of the reactions 
(a)

S6 (RNA primer)
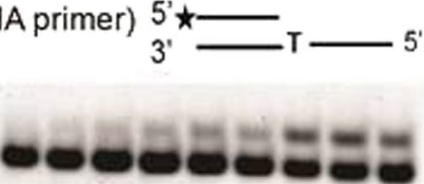

[dATP] $(\mu \mathrm{M})$
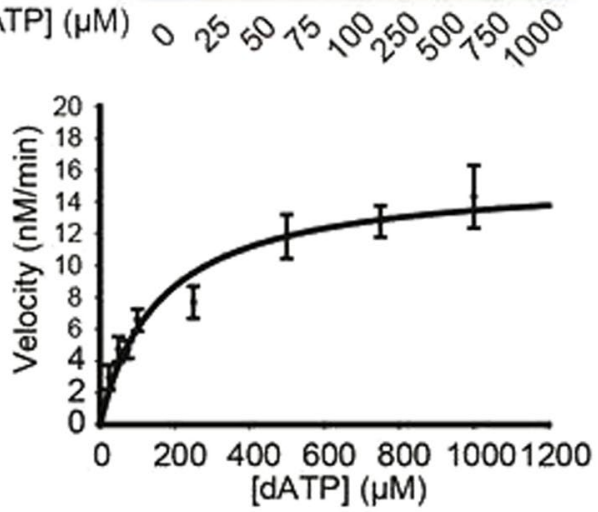

(c)
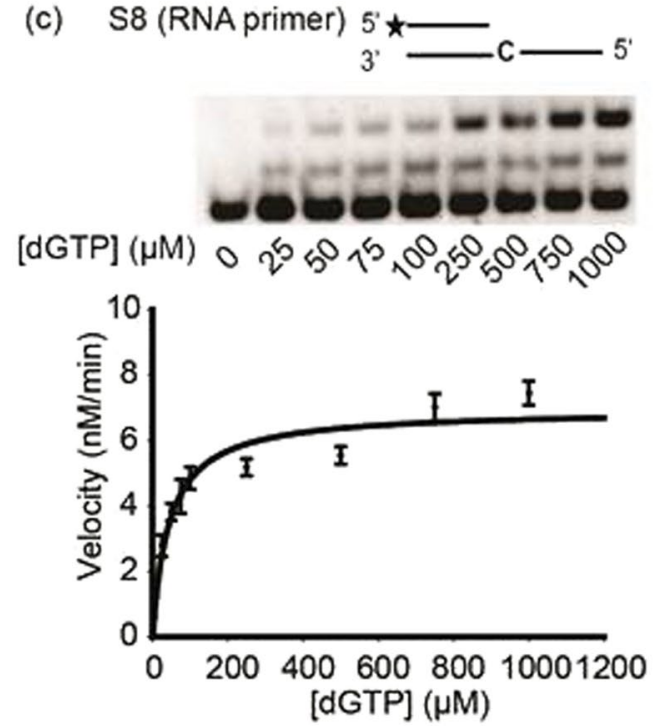

(b) S7 (RNA primer)
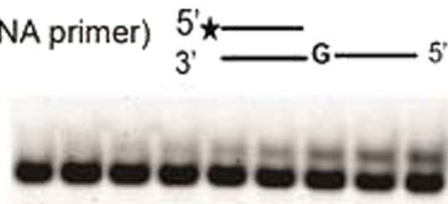

$[\mathrm{dCTP}](\mu \mathrm{M}) \circ \eta_{0} 50$ గ

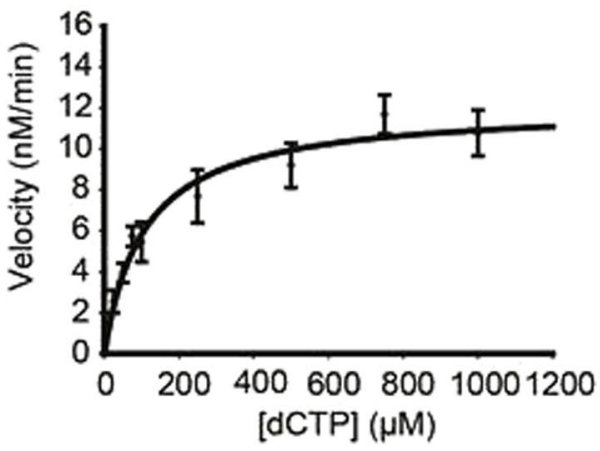

(d)
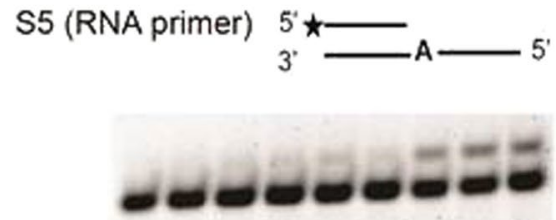

[dTTP] $(\mu \mathrm{M}) \circ \Upsilon_{0} 50$ 1

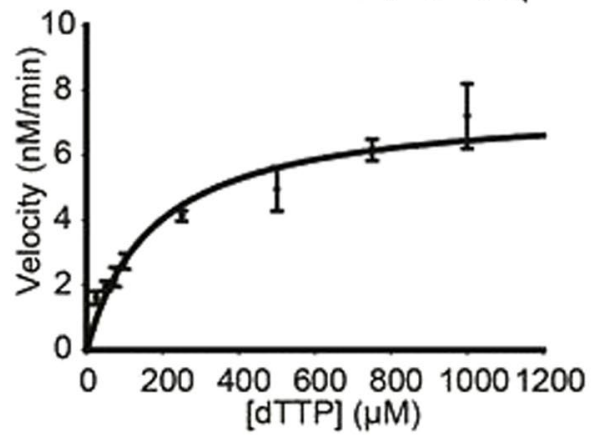

Figure 3. Steady-state kinetic analysis of RNA extension with dNTPs by Pol $\eta$. Gel pictures of RNA primer extensions with (a) dATP, (b) dCTP, (c) dGTP, (d) dTTP are shown at the top of each panel. Pol $\eta(1 \mathrm{nM})$ was incubated with $24 \mathrm{nM}$ of the indicated templates in the presence of increasing concentrations of the single incoming dNTP, as shown under the gel pictures. The quenched samples were analyzed by denaturing polyacrylamide gel electrophoresis, and quantified as described (see Materials and Methods). For each dNTP the rate of incorporation is plotted as a function of dNTP concentrations. The data were fit to the MichaelisMenten equation (see Materials and Methods). See Fig. S4 for full-length images.

(Table 4). Repeating the experiments using the corresponding single dNTPs instead of rNTPs revealed that lesion bypass during RNA synthesis is more efficient when Pol $\eta$ inserts dNTPs (Fig. 4e and j, Fig. S6 and Table 4). As Table 4 shows, even at intracellular nucleotide concentrations both 8 -oxoG and TT dimer bypass are $\sim 19$ times more efficient with dNTPs compared to rNTPs. In summary, these experiments indicate that although Pol $\eta$ is able to carry out error-free DNA lesion bypass during RNA extension using rNTPs, it preferentially inserts dNTPs opposite these lesions.

rad30 $\Delta$ cells are sensitive to transcription inhibitors. To investigate whether the newly discovered RNA synthetic activity of Pol $\eta$ can have functional significance, we asked whether Pol $\eta$ could be linked to transcription. To address this question, we first investigated the sensitivity of yeast rad 30 deletion strains to the widely used transcription inhibitor 6-azauracil (6-AU). 6-AU depletes the cellular levels of the RNA precursors UTP and GTP by inhibiting IMP dehydrogenase ${ }^{24}$. Consequently, transcription elongation becomes susceptible to perturbations and as a result, many elongation mutants were shown to exhibit sensitivity to the drug ${ }^{25-27}$. Surprisingly, rad30 $\Delta$ cells showed marked sensitivity to 6-AU compared to wild-type cells (Fig. 5a). This prompted us to 


\begin{tabular}{|l|l|l|l|l|l|l|}
\hline $\begin{array}{l}\text { Insertion } \\
\text { opposite }\end{array}$ & $\begin{array}{l}\text { Incoming } \\
\text { nucleotide }\end{array}$ & $\mathbf{k}_{\text {cat }}\left(\mathbf{m i n}^{-1}\right)$ & $\mathbf{K}_{\mathbf{m}}(\boldsymbol{\mu M})$ & $\mathbf{k}_{\text {cat }} / \mathbf{K}_{\mathbf{m}}$ & $\begin{array}{l}\text { nucleotide } \\
\text { concentration } \\
(\boldsymbol{\mu M})\end{array}$ & $\begin{array}{l}\text { Relative } \\
\text { frequency }\end{array}$ \\
\hline $\mathrm{T}$ & dATP & $15.607 \pm 1.227$ & $158.94 \pm 39.16$ & $98.19 \mathrm{E}-03$ & 16 & 1.02 \\
\hline $\mathrm{T}$ & rATP & $0.2394 \pm 0.0065$ & $466.4 \pm 47.29$ & $0.51 \mathrm{E}-03$ & 3000 & \\
\hline $\mathrm{G}$ & dCTP & $12.085 \pm 0.786$ & $107.7 \pm 24.7$ & $112.20 \mathrm{E}-03$ & 14 & 0.52 \\
\hline $\mathrm{G}$ & rCTP & $2.758 \pm 0.062$ & $438.3 \pm 37.52$ & $6.29 \mathrm{E}-03$ & 500 & \\
\hline $\mathrm{C}$ & $\mathrm{dGTP}$ & $6.9332 \pm 0.2768$ & $44.35 \pm 7.92$ & $156.31 \mathrm{E}-03$ & 12 & 2.35 \\
\hline $\mathrm{C}$ & rGTP & $0.4487 \pm 0.0149$ & $393.7 \pm 52.04$ & $1.14 \mathrm{E}-03$ & 700 & \\
\hline A & dTTP & $7.5753 \pm 0.5505$ & $174.49 \pm 38.01$ & $43.41 \mathrm{E}-03$ & 30 & 3.14 \\
\hline A & rUTP & $0.1032 \pm 0.0057$ & $423.3 \pm 90.45$ & $0.24 \mathrm{E}-03$ & 1700 & \\
\hline
\end{tabular}

Table 3. Kinetic parameters of dNTP or rNTP incorporation into RNA by Pol $\eta$. ${ }^{\mathrm{a}}$ In vivo dNTP and rNTP concentrations are according to ref. ${ }^{14}$. Values were obtained from results shown in Figs 2 and 3, and represent the mean and standard error of at least three experiments. Relative frequency of incorporation was calculated using the following equation: $f_{\text {rel }}=\left(\mathrm{k}_{\mathrm{cat} 1} / \mathrm{K}_{\mathrm{m} 1}\right) *[\mathrm{dNTP}] /\left(\mathrm{k}_{\mathrm{cat} 2} / \mathrm{K}_{\mathrm{m} 2}\right) *[\mathrm{rNTP}]$, where $\mathrm{k}_{\mathrm{cat} 1} / \mathrm{K}_{\mathrm{m} 1}$ is the value for $\mathrm{dNTP}$ incorporation and $\mathrm{k}_{\mathrm{cat} 2} / \mathrm{K}_{\mathrm{m} 2}$ is the one for $\mathrm{rNTP}$ incorporation.

investigate the relationship of RAD30 to genes involved in transcription. We examined DST1 coding for the canonical elongation factor TFIIS, the elongation factor gene RPB9 coding for a small subunit of RNAPII, and SNF5 encoding a chromatin remodeler involved in transcriptional activation ${ }^{28-30}$. Whereas additional deletion of RAD30 did not change the 6-AU sensitivities of the dst $1 \Delta$ and $r p b 9 \Delta$ elongation factor mutant strains, it further sensitized the snf5 $\Delta$ strain (Fig. 5a). Similar results were obtained using mycophenolic acid (MPA), another inhibitor of IMP dehydrogenase (Fig. 5b) $)^{31}$, suggesting that the absence of Pol $\eta$ might cause a defect in transcription.

The lack of RAD30 affects inducible and constitutive gene expression. Sensitivity to 6-AU and MPA can be indicative of transcriptional defects, however, deletion of some genes involved in other cellular processes also confer sensitivity to these drugs ${ }^{32}$. On the other hand, reduced transcriptional induction of the IMD2 gene, encoding IMP dehydrogenase, by 6 -AU or MPA is characteristic of genuine transcriptional mutants ${ }^{26}$. To define whether the observed 6-AU sensitivity of rad30 $\Delta$ cells actually reflected impairment of transcription, we first examined the induced synthesis of the IMD2 mRNA in the presence of 6-AU by reverse transcription followed by real time quantitative PCR (RT-qPCR). Indeed, $60 \%$ reduction in transcription, as monitored by $I M D 2$ induction, was observed in rad30 $\Delta$ cells suggesting that $R A D 30$ contributes to efficient gene expression (Fig. 5c). Investigation of two other commonly examined loci the galactose inducible GAL10 and GAL1 genes ${ }^{33,34}$, strengthened these results. As shown in Fig. 5d and Fig. S7, a 40\% decrease in the GAL10 and GAL1 mRNA levels could be detected in rad30 $\Delta$ cells compared to the wild-type strain. The $d s t 1 \Delta$ and $d s t 1 \Delta \mathrm{rad} 30 \Delta$, as well as the $r p b 9 \Delta$ and $r p b 9 \Delta$ rad30 $\Delta$ mutants exhibited comparable levels of $G A L$ gene expression, consistent with the 6-AU sensitivities of these strains. Next we tested whether constitutive transcription was also affected in rad30 $\Delta$ by investigating the UBC6 and TRP3 genes whose mRNA levels were shown to be stable in wild-type cells ${ }^{35,36}$. We found that the expression of these genes was reduced by $\sim 50-70 \%$ in rad $30 \Delta$ cells compared to wild-type cells (Fig. $5 \mathrm{e}$ and $\mathrm{f}$ ). Transcription levels in rad $30 \Delta$ cells were also monitored by luciferase reporter assays. We measured the activity of the firefly luciferase driven from the induced GAL1 promoter and observed a $\sim 40 \%$ decrease in the rad30 $\Delta$ compared to the wild-type strain, whereas the decrease was $\sim 60 \%$ in the $d s t 1 \Delta$ mutant (Fig. $5 \mathrm{~g}$ ). Similarly, the activity of the renilla luciferase expressed from the strong, constitutive glyceraldehyde-3-phosphate dehydrogenase promoter decreased to $\sim 50 \%$ of the wild-type level in rad $30 \Delta$ cells (Fig. $5 \mathrm{~h}$ ). These results support the view that deletion of $R A D 30$ influences transcription causing a marked decrease in the mRNA levels of different genes.

rad30 $\Delta$ cells exhibit transcriptional defect even when DNA synthesis is inhibited. Our next aim was to define whether the observed transcriptional defect of rad30 $\Delta$ cells could originate from the role of Pol $\eta$ in DNA synthesis. We surmised that in the absence of Pol $\eta$, replication complexes could stall more frequently and for longer times resulting in the block of transcription; alternatively, single-stranded gaps generated by NER could inhibit transcription if Pol $\eta$ was involved in the gap-filling step. This latter assumption takes into consideration the findings that the TLS DNA polymerases, mouse Polk and yeast Pol $\zeta$ function in NER as well ${ }^{37,38}$. Also, in Escherichia coli the TLS DNA polymerase DinB was found to interact with the transcription elongation factor NusA $^{39}$. It was suggested that NusA recruits DinB to transcription complexes stalled at single-stranded gaps generated by NER, where it participates in gap-filling. To investigate these possibilities, we examined a rad $1 \Delta$ rad $30 \Delta$ double mutant strain arrested in the G1 phase of the cell cycle. Under these conditions NER is inactive due to the lack of the Rad1 endonuclease essential for NER, and replication is inhibited by cell cycle arrest. Importantly, even under these conditions, rad $30 \triangle$ cells displayed defects in GAL10 and GAL1 gene transcription similarly to the previous experiments indicating that the observed effect on transcription was independent of the role of Pol $\eta$ in replication and in repair synthesis (Fig. 5i and Fig. S7). In addition, since transcription-coupled NER is non-functional in the absence of Rad1, the transcriptional impairment of rad30 $\Delta$ cells could not stem from a possible involvement of Pol $\eta$ in this process. 
(a)

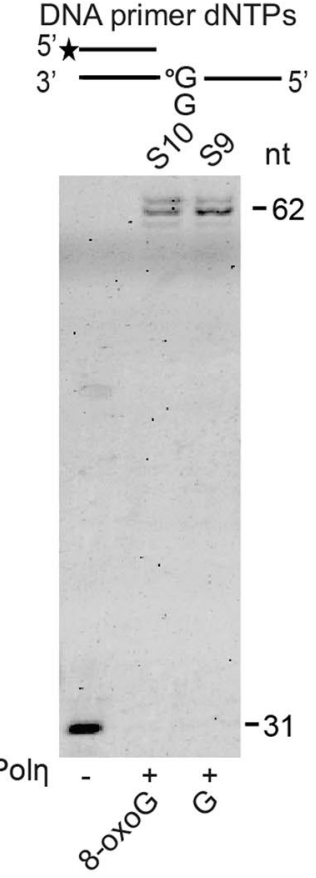

(f)

DNA primer dNTPS
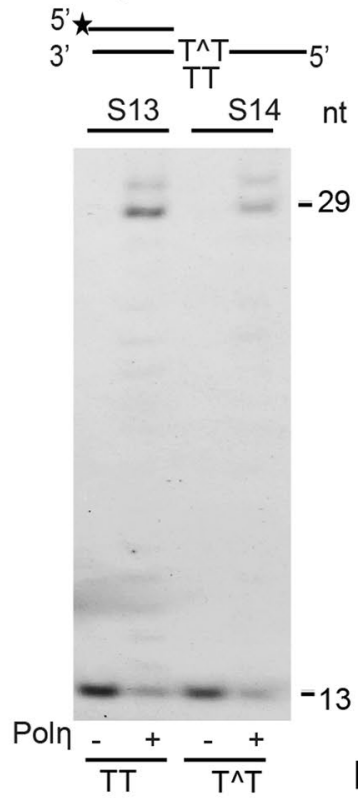

(b) RNA primer rNTPs

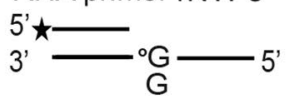
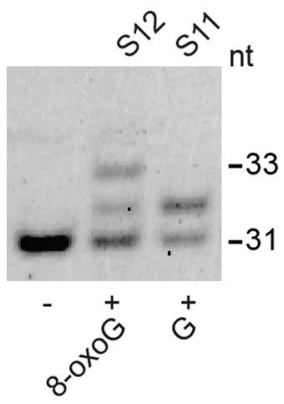

(d)

S12 (RNA primer)

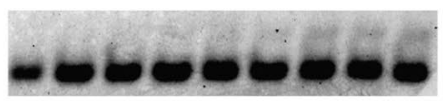

[rCTP] $(\mu \mathrm{M})$

(g)

RNA primer rNTPs
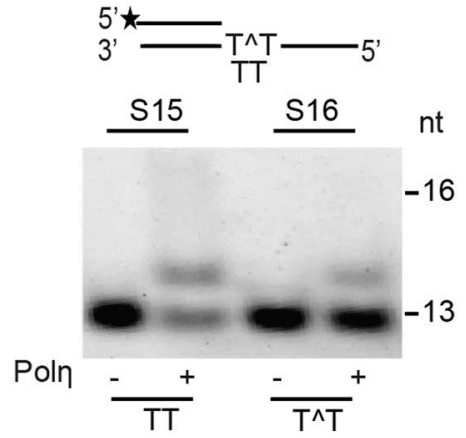

(i)

S16 (RNA primer)

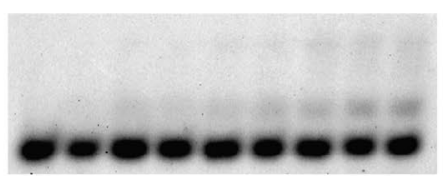

[rATP] $(\mu \mathrm{M})$

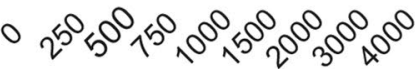

(c) S12 (RNA primer)
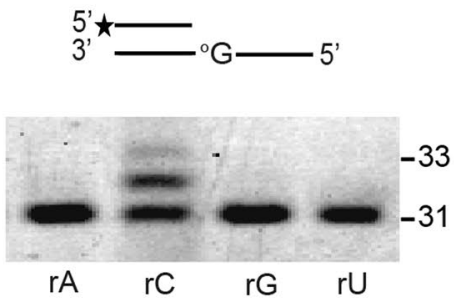

(e) S12 (RNA primer)

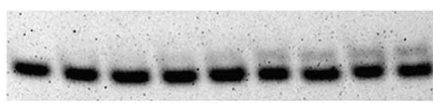

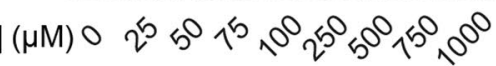

(h)

\section{S16 (RNA primer)}
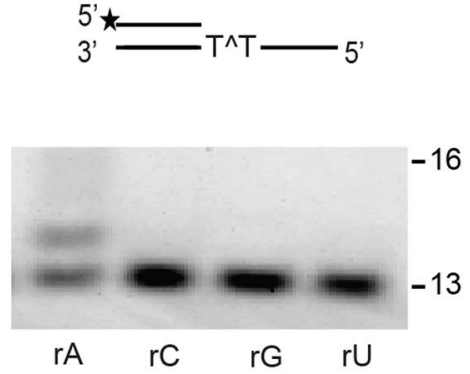

(j)

\section{S16 (RNA primer)}

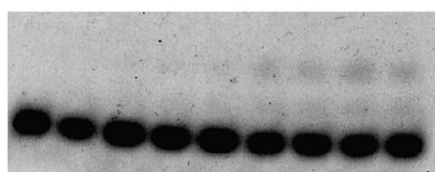

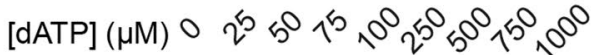

Figure 4. Pol $\eta$ can carry out error-free bypass of 8-oxoG and TT dimer during RNA extension. (a) Pol $\eta$ $(56 \mathrm{nM})$ can synthesize through a $\mathrm{G}$, and an 8-oxoG containing template (8nM both) during DNA extension with dNTPs $(100 \mu \mathrm{M})$ and $(\mathbf{b})$ also during RNA extension with rNTPs $(100 \mu \mathrm{M})(\mathbf{c})$ Pol $\eta(10 \mathrm{nM})$ inserts only the correct C ( $4 \mathrm{mM}$ of each rNTP) opposite 8-oxoG $(8 \mathrm{nM})$. (d) Kinetic assay for rCTP and (e) dCTP insertion opposite 8-oxoG. (f) Pol $\eta(18 \mathrm{nM})$ can synthesize through an undamaged TT and a TT dimer containing template (16 nM both) during DNA extension with dNTPs $(100 \mu \mathrm{M})$, as well as $(\mathbf{g})$ during RNA extension with rNTPs (1 mM). (h) Pol $\eta(18 \mathrm{nM})$ inserts only the correct A ( $4 \mathrm{mM}$ of each rNTP) opposite a TT dimer $(16 \mathrm{nM})$. (i) Kinetic assay of rATP and (j) dATP insertion opposite a TT dimer. In reactions shown in (d,e) $1 \mathrm{nM}$ Pol $\eta$ was incubated with $8 \mathrm{nM}$ template. In $(\mathbf{i}, \mathbf{j})$ reactions contained $1 \mathrm{nM}$ Pol $\eta$ and $16 \mathrm{nM}$ template. Conditions for the kinetic assays of $(\mathbf{d}, \mathbf{e}, \mathbf{i}, \mathbf{j})$ are detailed in Materials and Methods. The positions of the normal G or 8-oxoG $\left({ }^{\circ} \mathrm{G}\right)$, and the two Ts or the TT dimer $(\mathrm{T} \Lambda \mathrm{T})$ in the substrates are indicated Asterisks mark the $5^{\prime} \mathrm{Cy} 3$ labeled ends. See Fig. S5 for full-length images. 


\begin{tabular}{|l|l|l|l|l|l|l|}
\hline $\begin{array}{l}\text { Insertion } \\
\text { opposite }\end{array}$ & $\begin{array}{l}\text { Incoming } \\
\text { nucleotide }\end{array}$ & $\mathbf{k}_{\text {cat }}\left(\mathbf{m i n}^{-1}\right)$ & $\mathbf{K}_{\mathbf{m}}(\boldsymbol{\mu M})$ & $\mathbf{k}_{\text {cat }} / \mathbf{K}_{\mathbf{m}}$ & $\begin{array}{l}\text { nucleotide } \\
\text { concentration }\end{array}$ & $\begin{array}{l}\text { Relative } \\
\mathbf{f r e q u e n c y}\end{array}$ \\
\hline oxoG & dCTP & $1.7018 \pm 0.1177$ & $69.85 \pm 18.53$ & $24.36 \mathrm{E}-03$ & 14 & 19.4 \\
\hline oxoG & rCTP & $0.03424 \pm 0.00358$ & $973.97 \pm 270.44$ & $3.53 \mathrm{E}-06$ & 500 & \\
\hline TT dimer & dATP & $4.9105 \pm 0.5331$ & $287.12 \pm 83.85$ & $17.10 \mathrm{E}-03$ & 16 & 18.6 \\
\hline TT dimer & rATP & $0.00831 \pm 0.00106$ & $1677.9 \pm 444.8$ & $4.95 \mathrm{E}-06$ & 3000 & \\
\hline
\end{tabular}

Table 4. Kinetic parameters of dNTP or rNTP incorporation by Pol $\eta$ into RNA opposite DNA damages. ${ }^{\mathrm{a}}$ In vivo dNTP and rNTP concentrations are according to ref. ${ }^{14}$. Values were obtained from results shown in Fig. 4 , and represent the mean and standard error of three experiments. Relative frequency was calculated using the formula as for Table 3.

Deletion of RAD30 affects transcription elongation in vivo. To further corroborate the connection between $R A D 30$ and transcription, we examined transcription elongation by employing the G-less-based run-on (GLRO) method developed for direct in vivo analysis of elongation on chromatin ${ }^{40}$. In this assay, the amount of nascent mRNA synthesized in the cells over a promoter distal G-less cassette is compared to the amount of mRNA synthesized over a promoter proximal G-less cassette, the two cassettes being separated by a long, G-rich sequence that is refractory to elongation (Fig. 6a). RNase T1 digestion of total cellular RNA degrades all G-containing sequences leaving the two G-less cassettes intact that can be visualized and measured after polyacrylamide gel electrophoresis. In our hands, transcription elongation efficiency of the second cassette in the control spt4 $\Delta$ strain, used originally to validate the method, was $\sim 20 \%$ of the wild-type value, in good agreement with the published data (Fig. $6 \mathrm{~b}$ and c). Notably, in rad $30 \Delta$ cells, elongation efficiency was reduced to $\sim 60 \%$ of the wild-type level. These observations are consistent with the results obtained from the RT-qPCR and luciferase assays shown in Fig. 5 and support a potential role of Pol $\eta$ in transcription elongation.

Pol $\eta$ is enriched over the actively transcribed GAL1 gene. Next we investigated whether Pol $\eta$ co-localized with transcriptionally active regions, as predicted by the above experiments. For this purpose we examined the enrichment of Myc-tagged Pol $\eta$ at the GAL1 gene relative to an intergenic region, using chromatin immunoprecipitation (ChIP) experiments ${ }^{41,42}$. To avoid detecting enrichment due to ongoing replication, cells were arrested in the G1 phase of the cell cycle (Fig. S9). Our results show that whereas a small, 2 fold increase could be detected at the upstream activating sequence (UAS) when shifting cells from raffinose to galactose, the level of Pol $\eta$ enrichment increased 5-8 fold over the open reading frame (ORF) of the GAL1 gene after transcription induction (Fig. 6d). In contrast, no increase could be observed over a non-transcribed intergenic region. As controls, chromatin immunoprecipitations were performed with or without galactose induction in Gcn5-Myc and Spt5-Myc expressing as well as in non-tagged strains. In these experiments, as expected, the transcriptional co-activator histone acetyltransferase Gcn5 increased preferentially at the UAS (Fig. S9b), whereas the elongation factor Spt5 exhibited high enrichment over the ORF (Fig. S9c). In the non-tagged control strain, non-specific enrichment could not be detected. Taken together, these data show preferential enrichment of Pol $\eta$ over the ORF of the active GAL1 gene suggesting that Pol $\eta$ is specifically recruited to sites of active transcription.

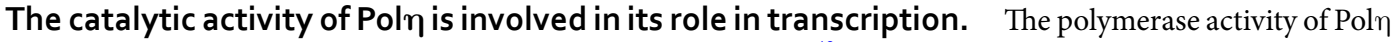
is essential for its known in vivo functions during DNA synthesis ${ }^{43}$. To address whether the polymerase activity of Pol $\eta$ was necessary for its new transcriptional role as well, we generated a strain expressing the catalytically inactive Pol $\eta$ D30A mutant from the genomic RAD30 locus. This was achieved by integrating back the wild-type or a mutant RAD30 copy coding for the D30A mutant protein into a rad30 $\Delta$ strain. First, we verified by Western blot analysis that both the wild-type and mutant reintegrated genes expressed similar Pol $\eta$ levels (Fig. S10a). Next, we examined the sensitivity of the strains to different agents. As expected, reintegration of the wild-type sequence suppressed the UV and 6-AU sensitivities of the rad30 $\Delta$ strain to the wild-type level confirming that both the enhanced UV and 6-AU sensitivities were indeed due to the lack of Pol $\eta$ (Fig. 7a). On the other hand, reintegration of the sequence coding for the D30A mutant protein rescued neither the UV nor the 6-AU sensitivity of the rad30 $\Delta$ null mutant. Accordingly, the Poln D30A mutant negatively affected activation of GAL10 and GAL1 genes similarly to rad30 $\Delta$, whereas this was not the case for the reintegrated wild-type RAD30 (Fig. $7 \mathrm{~b}$ and Fig. S10b). Importantly, chromatin immunoprecipitation experiments showed that the association of RNA PolII CTD with the active GAL1 gene was significantly reduced $(\mathrm{p}=0.0015)$ at the $3^{\prime}$ end in the D30A mutant compared to wild type, consistent with a defect in transcription elongation in this strain (Fig. 7c). In summary, these results indicate that the catalytic activity of Pol $\eta$ is required for its role in transcription.

\section{Discussion}

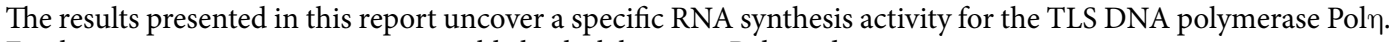
Furthermore, in vivo experiments establish a link between Pol $\eta$ and transcription.

The specificity of the novel RNA synthesis activity of Pol $\eta$ was assessed in steady-state kinetic experiments. This analysis revealed that Pol $\eta$ recognizes RNA as its substrate incorporating rNTPs into RNA an order of magnitude more efficiently than into DNA. Furthermore, Pol $\eta$ could carry out TT dimer and 8-oxoG bypass during RNA extension by preferentially incorporating the correct A or C residue opposite the damage, respectively. These observations are paralleled by in vivo experiments supporting a connection between Pol $\eta$ and transcription. By measuring mRNA levels from inducible and constitutive promoters, we showed that transcription was generally diminished in the absence of Pol $\eta$. This defect was independent of the DNA synthetic role of Pol $\eta$ as it could 


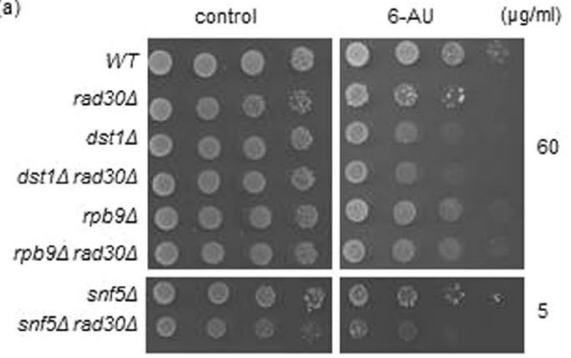

(b)

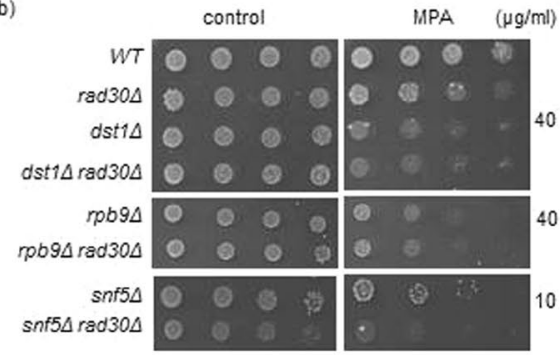

(c)

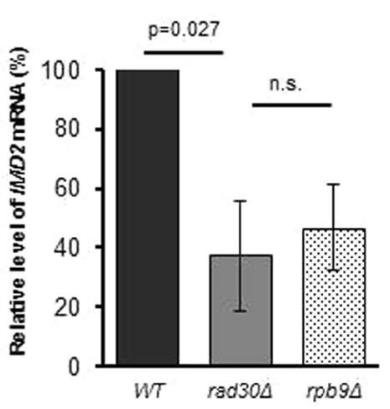

(e)

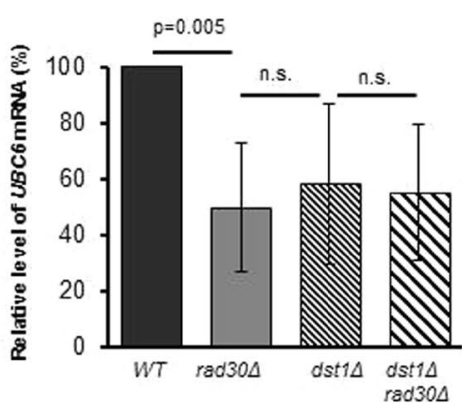

(d)

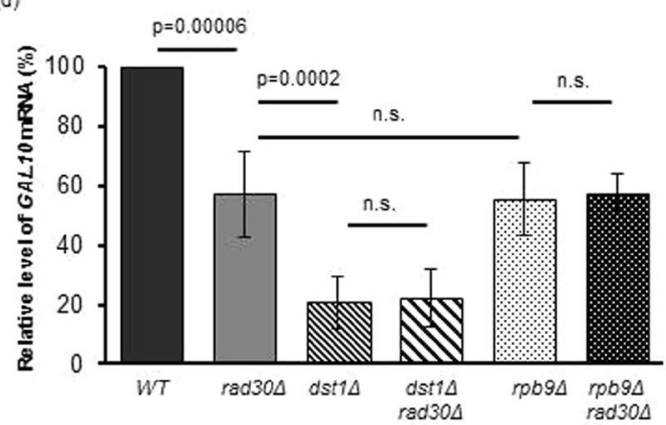

(f) (g)

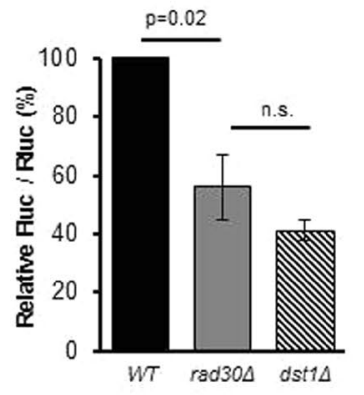

(h)

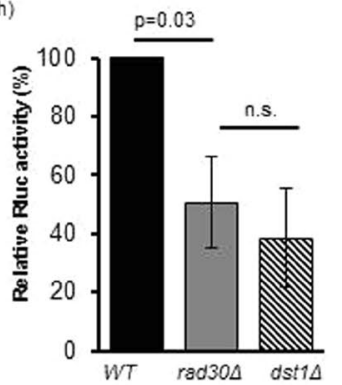

(i)

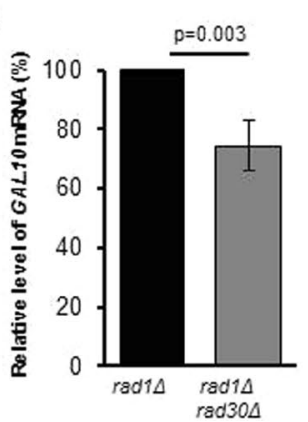

Figure 5. The absence of $R A D 30$ affects transcription. (a) rad30 $\Delta$ strains exhibit sensitivity to the elongation inhibitor 6-azauracil (6-AU) and (b) to mycophenolic acid (MPA). Ten fold serial dilutions of the strains with the indicated genotypes were spotted on media containing the indicated concentration of the appropriate drugs. (c) 6-AU induced mRNA level of the IMD2 gene and (d) galactose induced mRNA level of the GAL10 gene in the presence of MPA decreased in the rad30 $\Delta$ strain, as measured by RT-qPCR. (e) Constitutive expressions of the UBC6 and (f) TRP3 genes in the presense of 6-AU are decreased in the absence of RAD30, as measured by RT-qPCR. (g) Firefly luciferase activity expressed from the induced GAL1 promoter is lowered in rad $30 \Delta$ cells. (h) Renilla luciferase activity, driven from the constitutive GPD promoter, is diminished in the absence of RAD30. (i) Deletion of RAD30 causes transcriptional defect even in G1-arrested, NER defective cells, as measured by RT-qPCR. Panels ( $c-f$ and $i$ ) show relative mRNA levels measured by RT-qPCR normalized to SED1 mRNA. In panels $(\mathbf{g}, \mathbf{h})$ relative enzyme activities are presented. In panels $(\mathbf{c}-\mathbf{i})$ the values obtained for the wild-type strain were set to $100 \%$ and the values obtained with the deletion strains are shown relative to that. Data are presented as mean $\pm S D$ of at least 3 experiments. $p$ values are indicated, ns: no statistical difference. 
(a)

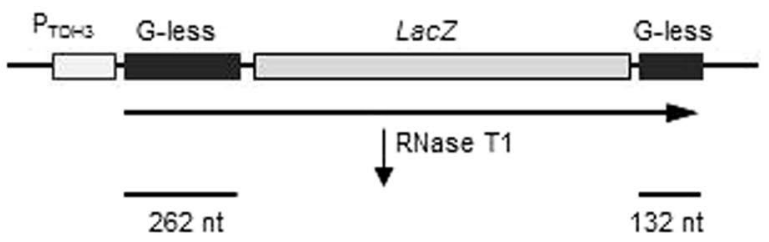

(b)

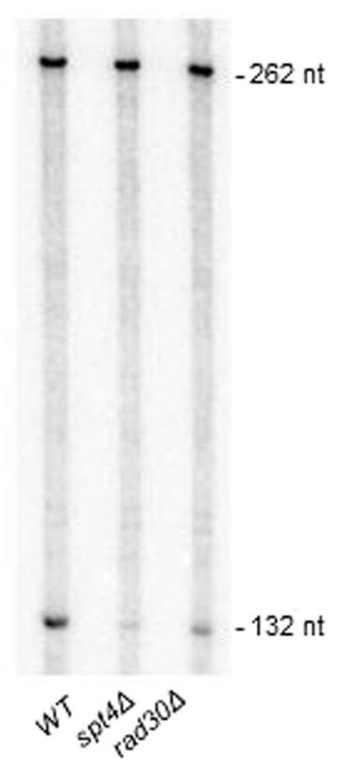

(c)

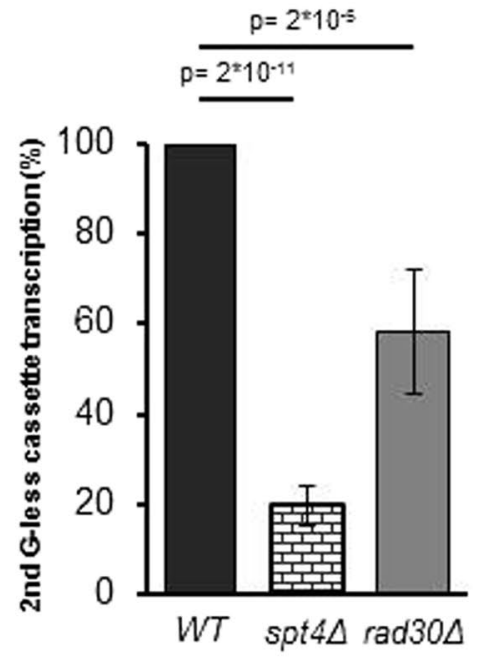

(d)

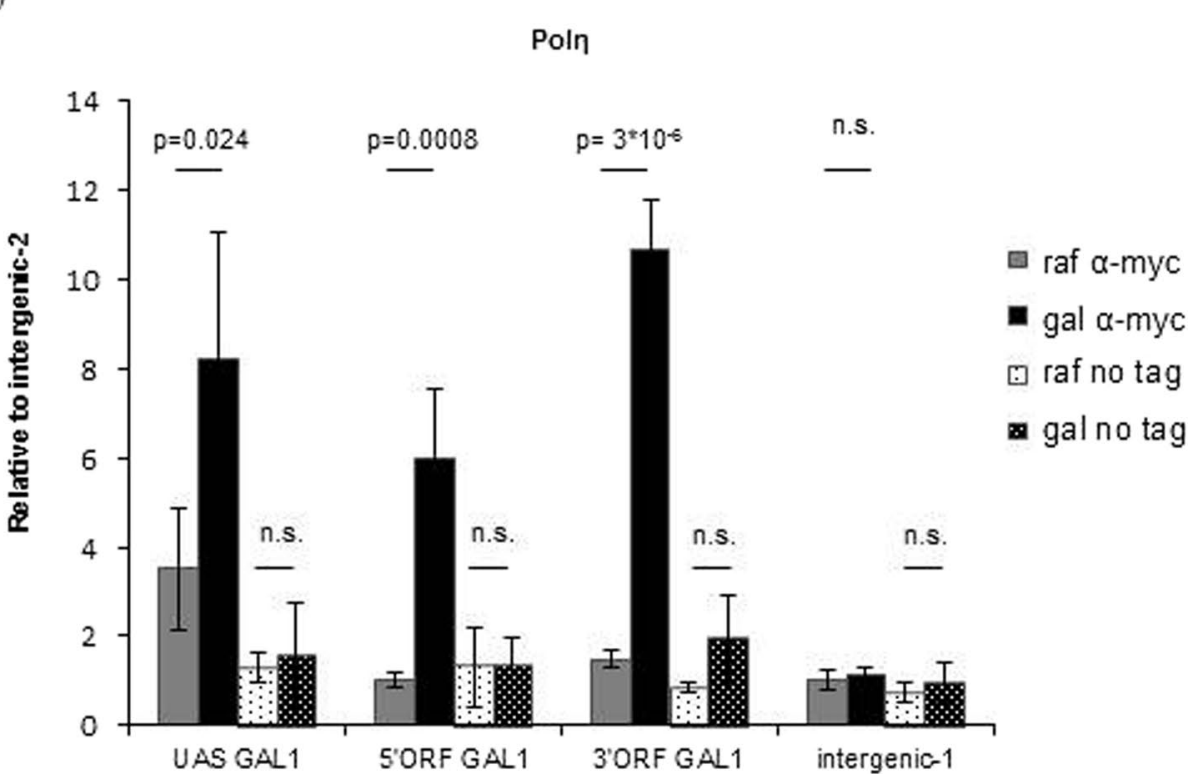

Figure 6. Pol $\eta$ affects elongation in vivo and is enriched over the active GAL1 gene (a) Schematic drawing of the G-less based run-on (GLRO) assay. The sizes of the two G-less cassettes are shown. (b) GLRO analysis was performed with the indicated strains transformed with the GLRO-long plasmid. A representative gel picture is shown. See Fig. S8 for the full-length image. (c) Quantification of the results of four independent GLRO experiments. For each sample, the ratio of total counts incorporated into the distal versus the proximal G-less cassettes was normalized to the ratio in the wild-type strain, which was set to $100 \%$. (d) Occupancy of Pol $\eta$ on the UAS, 5'ORF, 3'ORF of the GAL1 gene and on two independent intergenic regions in uninduced (raf) and induced (gal) conditions was measured by chromatin immunoprecipitation (ChIP) using anti-Myc antibody in a strain arrested in G1, and expressing C-terminally Myc-tagged Pol $\eta$. As control, ChIP was also performed with an untagged strain (no tag). Percentage of input at the indicated regions was normalized to intergenic region 2 on chromosome IV. Experiments were repeated at least 3 times. Mean and standard deviations are indicated, p-values were calculated by 2-tailed t-test, n.s.: no statistical difference. 


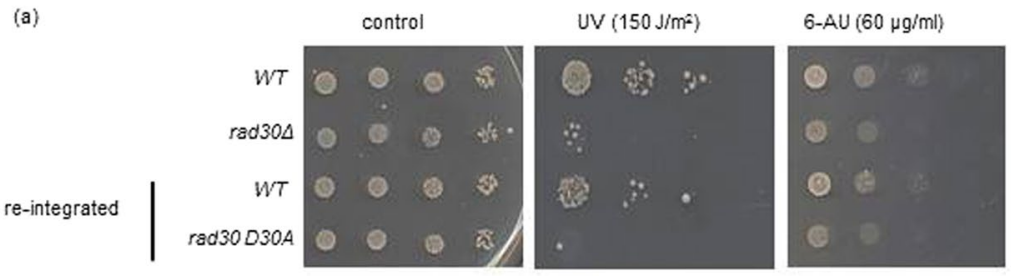

(b)

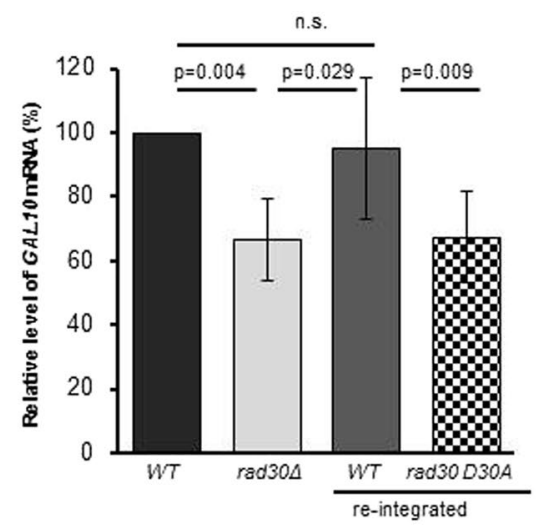

(c)

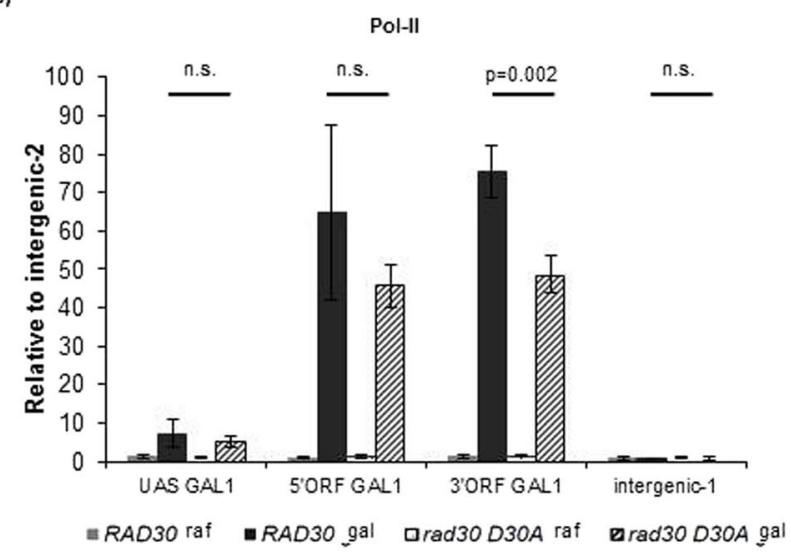

Figure 7. Catalytic inactivation of Pol $\eta$ causes similar defects as the deletion of the RAD30 gene. (a) Strains carrying the Pol $\eta$ D30A mutant are sensitive to both UV and 6-AU. Ten fold serial dilutions of the indicated strains were spotted on media containing the indicated concentration of 6-AU, or irradiated with the indicated UV-dose after spotting. (b) Induced level of GAL10 mRNA is decreased in the Pol $\eta$ D30A mutant, as measured by RT-qPCR. The mean value obtained for the wild-type strain was set to $100 \%$ and the values obtained with

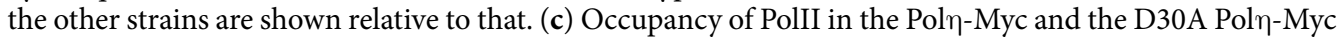
mutant expressing strains was measured with ChIP using anti-Myc antibody as described in Fig. 6d. Mean and standard deviations based on at least 4 experiments are indicated, $\mathrm{p}$-values were calculated by 2 -tailed t-test,n.s.: no statistical difference.

be detected even when replication and repair synthesis were inhibited. Chromatin immunoprecipitation and in vivo transcription run-on assays demonstrated that Pol $\eta$ was enriched over the ORF of the active GAL1 gene and affected transcription elongation. Taken together the in vivo results suggest a role for Pol $\eta$ in transcription thereby providing a possible setting for its specific RNA synthesis activity. In particular, the observation that the catalytically inactive protein causes similar defects in transcription in vivo as the lack of Pol $\eta$ suggests that the newly discovered specific RNA synthesis activity of Pol $\eta$ contributes to transcription. Probably the most obvious reason for Pol $\eta$ being associated with transcription could be to rescue stalled RNAPII, particularly by inserting ribonucleotides opposite DNA lesions, similar to its role in rescuing damage-stalled replication. Although in vitro damage bypass studies showed that RNAPII could bypass several small, non-distorting lesions, such as abasic sites, dihydrouracil and 8-oxoG, resulting in mutagenic transcripts ${ }^{44-46}$, still, bulky damages and CPDs induced a complete block to RNAPII. In vivo bypass of these lesions in nucleotide excision repair (NER) defective cells further suggested the existence of damage bypass mechanisms operating during transcription ${ }^{4-53}$. So far translesion RNA synthesis has been thought to be performed by RNAPII itself with the aid of elongation factors. Indeed, TFIIF, TFIIS, Elongin and CSB purified from HeLa cells were shown to help RNAPII to bypass certain oxidative DNA lesions ${ }^{54}$. Nevertheless, it remains elusive how RNAPII could bypass the high variety of lesions, and how it could overcome the blocks represented by CPDs and bulky damages. Based on our results, Poln could be a new candidate to help RNAPII to bypass DNA damage sites. However, our kinetic experiments demonstrated that Pol $\eta$ inserted dNTPs and rNTPs into RNA with similar efficiencies at intracellular nucleotide concentrations. Furthermore, though Pol $\eta$ could carry out error-free bypass of a TT dimer and 8-oxoG during RNA extension, damage bypass was an order of magnitude more efficient with dNTPs at intracellular nucleotide concentrations. These results indicate that if Pol $\eta$ participated in RNA synthesis in vivo, it could insert both rNTPs and dNTPs on undamaged templates, and it would most probably insert dNTPs opposite DNA lesions. This would have severe consequences by leading to the accumulation of dNTPs in RNA causing miscoding, affecting RNA structure ${ }^{55}$, RNA-protein interactions ${ }^{56}$, and RNA packaging ${ }^{57}$. To resolve this problem we presume that cellular factors can modify the kinetics of the reactions. Indeed, the DNA replication factor PCNA together with the clamp loader RFC and the ssDNA binding protein RPA were shown to stimulate the DNA synthetic activity of Pol $\eta$ with an order of magnitude on undamaged templates, and with two orders of magnitude opposite an abasic residue ${ }^{11,12}$. To get access to the nascent RNA, Pol $\eta$ is likely to form interactions with members of the elongation machinery, and as with its interaction with replication factors, these interactions could modulate the activity and/or selectivity of Pol $\eta$ so that rNTP insertion would be preferred opposite to undamaged as well as damaged bases. 
Our hypothesis introduces a new concept: transcriptional DNA lesion bypass mediated by polymerase switch. Polymerase switch during transcription has long been ruled out because of the need for specific promoter elements to start transcription. Nevertheless, RNAPII has been shown to be able to pause, move backwards at stall sites, and transcription could be reactivated from the stalled state proving the elongating complex to be much more flexible than previously assumed ${ }^{58-60}$. We presume that this flexibility could support the consecutive steps of polymerase exchange at transcription complexes stalled at DNA damage sites.

Our hypothetical model could explain puzzling earlier observations detecting mammalian Pol $\eta$ foci formation after UV treatment in cells where replication and repair synthesis were inhibited ${ }^{61}$. Poln foci formation occurred in chinese hamster ovary and in human cell lines arrested in the G1 phase of the cell cycle. It was independent of PCNA, and inactivation of NER did not influence Pol $\eta$ foci, either. Several studies demonstrated that transcription takes place at discrete foci in the nucleus called transcription factories ${ }^{62-64}$. We suggest that the transcriptional role of Pol $\eta$ might be conserved through evolution and that the observed foci formation of mammalian Pol $\eta$ could represent its recruitment to stalled transcription elongation complexes at transcription factories.

During the course of this work, a few studies have been published examining rNTP incorporation by yeast or human Pol $\eta$. They showed that yeast Pol $\eta$ is very inefficient in extending a DNA primer with $\mathrm{rNTPs}^{20}$, whereas human Pol $\eta$ can extend a DNA primer with several rNTPs and even bypass DNA lesions such as 8-oxoG and TT dimers using ribonucleotides ${ }^{65,66}$. However, to our knowledge, the current study is the first showing specific RNA extension by a DNA polymerase and implicating this activity in transcription.

\section{Methods}

Yeast strains and plasmids. The wild-type strain BY4741 (MATa, his3- $\Delta 1$, leu2, met15, ura3) and its single deletion derivatives were obtained from the Euroscarf collection. Additional deletions were generated by gene replacement. Strains used in experiments involving synchronizing the cells in G1 phase were made bar1 $\Delta$ to achieve complete and stable cell cycle arrest. For detection during chromatin immunoprecipitation, 9 copies of the Myc tag was fused to the C-terminus of the RAD30, GCN5, and SPT5 genes at the genomic locus by applying a PCR-based method ${ }^{67}$. To generate the mutant Pol $\eta$ protein, site-specific mutagenesis was carried out by a PCR based method according to the "Quick Change Site Directed Mutagenesis" protocol (Stratagene, La Jolla, California). Reintegration of wild-type or mutant RAD30 was done by transforming a linear DNA fragment containing the RAD30 gene from -317 to 900 nucleotides after the stop codon, with the HIS3 marker gene inserted 632 nucleotides downstream of the stop codon, into rad30 $\Delta$ yeast cells. Genomic changes were confirmed by PCR and sequencing. The protease deficient yeast strain BJ5464 (MAT $\alpha$, his3- $\Delta 200$, leu2- $\Delta 1, \operatorname{trp} 1 \Delta$, ura3-52, pep4::HIS3, prb1- $\Delta 1.6 R$, can 1 ) was used for protein overexpression (ATCC stock centre). pCYC-LacZ (GLROLong) was used for GLRO assays ${ }^{40}$. The pY25GAL1-GPD dual promoter plasmid (Turbobiotech, Chang Cun, China) was used to clone the Renilla and Firefly luciferase genes under the GPD and GAL1 promoters, respectively. The luciferase genes with the respective promoters and terminators were further cloned into the centromeric plasmid YCplac33 to generate plasmid pID723 used in the luciferase assays. For protein purification, the wild-type and the D30A mutant Pol $\eta$ were overexpressed as $\mathrm{N}$-terminal fusions with the glutathione S-transferase (GST) gene from pID206 and pID797, respectively (pBJ842 backbone) ${ }^{68}$.

Poln purification. Wild-type and D30A mutant Pol $\eta$ were overexpressed in yeast as N-terminal fusions with GST and affinity purified on glutathione-Sepharose 4B beads (GE Healthcare) in a buffer containing $50 \mathrm{mM}$ Tris/ $\mathrm{HCl} \mathrm{pH}$ 7.0, $50 \mathrm{mM} \mathrm{KCl}, 100 \mathrm{mM} \mathrm{NaCl}, 10 \%$ sucrose, $0.5 \mathrm{mM}$ EDTA, $10 \mathrm{mM}$ 2-mercaptoethanol and protease inhibitors. After washing the column three times with $10 \mathrm{X}$ volume of a buffer containing $100 \mathrm{mM}$ Tris/ $\mathrm{HCl} \mathrm{pH}$ $7.5,1 \mathrm{M} \mathrm{NaCl}, 0.01 \% \mathrm{NP} 40,10 \%$ glycerol, and then two times with the same buffer but containing $100 \mathrm{mM} \mathrm{NaCl}$, the GST-tag was removed in the last step of the purification by incubating the beads with PreScission protease in a buffer (50 mM Tris/ $\mathrm{HCl}$ pH 7.5, $150 \mathrm{mM} \mathrm{NaCl}, 1 \mathrm{mM}$ EDTA, $1 \mathrm{mM}$ DTT, $0.01 \%$ Nonidet P-40, 10\% glycerol) at $4^{\circ} \mathrm{C}$ for 12 hours.

Primer extension assays. Standard reactions $(5 \mu \mathrm{l})$ contained $25 \mathrm{mM}$ Tris/ $\mathrm{HCl} \mathrm{pH} 7.5,5 \mathrm{mM} \mathrm{MgCl}, 1 \mathrm{mM}$ dithiothreitol, bovine serum albumin $(100 \mu \mathrm{g} / \mathrm{ml}), 10 \%$ glycerol, and the specified amount of template and substrate. Reactions were initiated by the addition of wild-type or mutant Pol $\eta$ at the indicated concentrations, incubated at $30^{\circ} \mathrm{C}$ and quenched by the addition of $10 \mu \mathrm{l}$ loading buffer containing $95 \%$ formamide, $18 \mathrm{mM}$ EDTA, $0.025 \%$ SDS, $0.025 \%$ bromophenol blue and $0.025 \%$ xylene cyanol. The reaction products were resolved on $10 \%$ polyacrylamide gels containing $8 \mathrm{M}$ urea and analyzed with a Typhoon TRIO Phosphorimager (GE Healthcare). Oligonucleotides used in these experiments were purchased from Integrated DNA Technologies, San Jose, California, except for the 8-oxoG containing primer that was from Midland Certified Reagent Co. Midland, Texas, and the TT-dimer containing oligonucleotide was from Trilink Biotechnologies, San Diego, California. Oligonucleotide sequences and the structures of substrates are shown in Table 1 . To facilitate detection, oligonucleotides labeled with the fluorophore indocarbocyanine $(\mathrm{Cy} 3)$ at the $5^{\prime}$-ends were used as primers.

Determination of steady-state kinetic parameters. For steady-state kinetics of RNA and DNA primer extensions with rNTPs on undamaged templates, Pol $\eta(1 \mathrm{nM})$ was incubated with $20 \mathrm{nM}$ of the DNA:DNA (S1-4) or DNA:RNA (S5-8) templates in standard buffer (as above). For dNTP insertion into RNA, $1 \mathrm{nM}$ Pol $\eta$ was incubated with $24 \mathrm{nM}$ template in standard buffer. Reactions were initiated by adding the corresponding single rNTP (varied from 0.25 to $4 \mathrm{mM}$ ) or $\operatorname{dNTP}\left(25-1000 \mu \mathrm{M}\right.$ ), and incubated at $30^{\circ} \mathrm{C}$ from $30 \mathrm{sec}$ to $60 \mathrm{~min}$. The intensity of the gel bands corresponding to the substrate and the product were quantitated with Typhoon TRIO Phosphorimager (GE Healthcare) using ImageQuant TL software (GE Healthcare) and the observed rates of nucleotide incorporation were plotted as a function of rNTP concentration. The data were fit by nonlinear regression using SigmaPlot program (version 12.5 Systat Software, San Jose, CA) to the Michaelis-Menten equation 
describing a hyperbola, $v=\left(V_{\max } \mathrm{X}[\mathrm{rNTP}] /\left(K_{m}+[\mathrm{rNTP}]\right)\right.$. The $k_{\text {cat }}$ and $K_{m}$ steady-state parameters were obtained from the fit and were used to calculate the efficiency of rNTP insertion into RNA versus DNA by using the following equation: $f_{\text {ext }}=\left(k_{c a t} / K_{m}\right)_{\mathrm{RNA}} /\left(k_{c a t} / K_{m}\right)_{\mathrm{DNA}}$ and dNTP versus $\mathrm{rNTP}$ insertion into RNA according to the formula $f_{\text {rel }}=\left(\mathrm{k}_{\mathrm{cat} 1} / \mathrm{K}_{\mathrm{m} 1}\right) *[\mathrm{dNTP}] /\left(\mathrm{k}_{\mathrm{cat} 2} / \mathrm{K}_{\mathrm{m} 2}\right) *[\mathrm{rNTP}]^{69}$.

Steady-state kinetic assay of DNA lesion bypass. For kinetic analysis of 8-oxoG bypass, $1 \mathrm{nM}$ Poln was incubated with $8 \mathrm{nM}$ template (S12) in standard buffer. Reactions were initiated by adding rCTP (0.25 to $4 \mathrm{mM})$ or dCTP $(25-1000 \mu \mathrm{M})$, and incubated at $30^{\circ} \mathrm{C}$ for $30 \mathrm{~min}$ and $1 \mathrm{~min}$, respectively. In case of TT dimer, $1 \mathrm{nM}$ Pol $\eta$ was incubated with $16 \mathrm{nM}$ template (S16) in standard buffer. Reactions were initiated by adding rATP $(0.25$ to $4 \mathrm{mM})$ or dATP $(25-1000 \mu \mathrm{M})$, and incubated at $30^{\circ} \mathrm{C}$ for $60 \mathrm{~min}$ and $2 \mathrm{~min}$, respectively. Reactions were visualized on $12 \%$ polyacrylamide gels containing $8 \mathrm{M}$ urea and quantitated as above.

Sensitivity Assays. For 6-AU sensitivity assays, strains were transfected with YCplac33 (URA3 expressing plasmid) and cultures were grown overnight in synthetic complete (SC) media lacking uracil (-ura). From these starter cultures, 10X serial dilutions were spotted on SC-ura plates containing the respective amounts of 6-AU. MPA sensitivity was assayed similarly, but cells were grown in and spotted on SC media containing the indicated amount of MPA. Plates were incubated at $30^{\circ} \mathrm{C}$ for $4-5$ days. For UV sensitivity assays, 10X serial dilutions of overnight cultures grown in YPD (yeast-peptone-dextrose) medium were spotted on YPD plates, irradiated with the respective UV doses and incubated in the dark at $30^{\circ} \mathrm{C}$ for $2-3$ days.

Luciferase Assays. Strains transformed with pID723 and grown in SC-ura medium were used to measure luciferase activity using the dual luciferase reporter assay system (Promega Corporation, Madison, Wisconsin). Firefly luciferase expression was induced by addition of $2 \%$ galactose to cultures at a density of $\mathrm{A}_{600}: 0.7$ and after $1 \mathrm{~h}$ cells were harvested. To measure the constitutive expression of renilla luciferase, logarithmically growing cells at $\mathrm{A}_{600}: 0.7$ were counted before measurements using a Bürker chamber, and activity was normalized to cell number. Luciferase measurements were carried out as described using a Fluoroskan Ascent FL microplate fluorometer and luminometer (Thermo Fischer Scientific Inc., Waltham, Massachusetts) ${ }^{70}$.

Analysis of mRNA levels by RT-qPCR. For measurement of $I M D 2, U B C 6$ and TRP3 mRNA levels, yeast strains transformed with YCplac33 were grown in SC-ura medium at $30^{\circ} \mathrm{C}$ with vigorous shaking. At $\mathrm{A}_{600}: 0.5$, 6 -AU was added to a final concentration of $70 \mu \mathrm{g} / \mathrm{ml}$. After $2 \mathrm{~h}$ cells were collected and quickly frozen at $-80^{\circ} \mathrm{C}$. For induction of GAL genes, yeast strains were grown in SC medium containing lactate as the sole carbon source (SCL). At $\mathrm{A}_{600}: 0.5$, MPA was added to a final concentration of $70 \mu \mathrm{g} / \mathrm{ml}$. After $2 \mathrm{~h}$, galactose was added to a final concentration of $2 \%$ to induce $G A L$ gene expression. $1 \mathrm{~h}$ after induction cells were collected and quickly frozen at $-80^{\circ} \mathrm{C}$. For synchronization in the $\mathrm{G} 1$ phase of the cell cycle, exponentially growing strains carrying deletion of the BAR1 gene were synchronized at $\mathrm{A}_{600}: 0.4$ in SCL by adding alpha mating factor (Sigma-Aldrich, St. Louis, MO, USA) to a final concentration of $50 \mathrm{ng} / \mathrm{ml}$. Synchronization was checked microscopically. After $3 \mathrm{~h}$ MPA was added to a final concentration of $70 \mu \mathrm{g} / \mathrm{ml}$, as well as more alpha factor to keep the cells in $\mathrm{G} 1$ phase. After $2 \mathrm{~h}$ with MPA, galactose was added to a final concentration of $2 \%$ and after another hour of incubation at $30^{\circ} \mathrm{C}$ cells were pelleted and quickly frozen to $-80^{\circ} \mathrm{C}$. Total RNA was purified using TRIzol Plus kit (Life Technologies, Carlsbad, California) according to the manufacturer's protocol, except cells were disrupted with glass beads. On-column DNase treatment was performed for 20 minutes using PureLink DNase. Reverse transcription of $0.5 \mu \mathrm{g}$ RNA was performed using oligo-dT primer and Revert Aid first strand cDNA synthesis kit (Thermo Fischer Scientific). Real-time qPCR was performed with SYBR-Green detection method on Light Cycler 480 (Hoffmann-La Roche, Basel, Switzerland) with the primers summarized in Table S1. The SED1 gene, whose mRNA level does not change significantly upon 6-AU or MPA treatment, or upon deleting RAD30, was used for normalization ${ }^{71}$.

G-less based run-on assay (GLRO). GLRO assays were carried out as previously described ${ }^{40,72}$. Briefly, the wild-type and mutant strains harboring the GLRO-long plasmid pCYC-LacZ were grown to an $\mathrm{A}_{600}: 0.5$ in SC-leu at $30^{\circ} \mathrm{C}$. Cells were permeabilized with $0.5 \%$ sarkosyl for $20 \mathrm{~min}$ on ice. Pelleted cells were resuspended in $71 \mu \mathrm{l}$ of ice-cold transcription mix (42.25 mM Tris/ $\mathrm{HCl} \mathrm{pH} \mathrm{7.7,} 422.5 \mathrm{mM} \mathrm{KCl}, 67.6 \mathrm{mM} \mathrm{MgCl}_{2}, 1.13 \mathrm{mM} \mathrm{ATP}, 1.13 \mathrm{mM}$ CTP, and $4.225 \mathrm{mM}$ dithiothreitol). Labeling of nascent transcripts was initiated by the addition of $50 \mu \mathrm{Ci}$ of $[\alpha-32 \mathrm{P}]$ UTP $(3,000 \mathrm{Ci} / \mathrm{mmol})$, and samples were incubated for $5 \mathrm{~min}$ at $27^{\circ} \mathrm{C}$. "Chase" was performed with the addition of $10 \mu \mathrm{l}$ of $25 \mathrm{mM} \mathrm{UTP}-0.25 \mathrm{mM}$ GTP for $10 \mathrm{~min}$ at $27^{\circ} \mathrm{C}$. Reactions were stopped by addition of $900 \mu \mathrm{l}$ of ice-cold AE buffer ( $50 \mathrm{mM}$ sodium acetate, $10 \mathrm{mM}$ EDTA pH 5.0). Total RNA was isolated using TRIzol (Life Technologies) and digested with RNaseT1, which only leaves G-less cassettes intact, for $2 \mathrm{~h}$ at $37^{\circ} \mathrm{C}$. After proteinase $\mathrm{K}$ treatment (Thermo Scientific), the remaining RNA was precipitated with ethanol as described, resuspended in formamide gel loading buffer (Life Technologies) and run on a 6\% denaturing urea-acrylamide gel. Dried gels were analyzed with Typhoon TRIO Phosphorimager (GE Healthcare, Little Chalfont, UK) using ImageQuant TL software (GE Healthcare) as described ${ }^{40}$.

Chromatin immunoprecipitation (ChIP). For ChIP experiments, cells were exponentially grown at $30^{\circ} \mathrm{C}$ in SC $+2 \%$ raffinose medium to $\mathrm{A}_{600}: 0.6-0.8$ and arrested in $\mathrm{G} 1$ during $4 \mathrm{~h}$ with alpha-factor $(20 \mathrm{ng} / \mathrm{ml})$. Synchronization efficiency was measured by FACS. To induce GAL1 gene expression $2 \%$ galactose was added to $\mathrm{G} 1$-arrested cells and cultures were grown for $1 \mathrm{~h}$ at $30^{\circ} \mathrm{C}$. Non-induced ( $2 \%$ raffinose) or induced ( $2 \%$ galactose) yeast cultures were cross-linked with $1 \%$ formaldehyde during 15 minutes and neutralized with $250 \mathrm{mM}$ glycine during $5 \mathrm{~min}$ at room temperature followed by $10 \mathrm{~min}$ on ice. Cultures were pelleted and washed twice with cold PBS buffer. All subsequent procedures were done at $4{ }^{\circ} \mathrm{C}$ unless otherwise stated. Pellets were resuspended in FA 
buffer (50 mM HEPES-KOH pH 7.5, 140 mM NaCl, 1 mM EDTA, 1\% Triton X-100, 0.1\% sodium deoxycholate, protease inhibitor cocktail (Roche)) and cells were disrupted with glass beads using a MagNA Lyser (4 times, $6000 \mathrm{rpm}$ ). Recovered lysates were sonicated to obtain chromatin fragments with an average size of 250-500 nt and centrifuged for $15 \mathrm{~min}$ at $18000 \mathrm{~g}$. The protein concentration of the supernatant was measured by Bradford and $1.5 \mathrm{mg}$ of total cell extract was incubated overnight with antibodies (anti-Myc 9E10 or anti-CTD PolII 8WG16 (Abcam)) and an additional $3 \mathrm{~h}$ with Dynabeads ${ }^{\circledR}$ Protein G (Thermo Fisher Scientific). After immunoprecipitation, beads were washed once with FA buffer, twice with FA buffer $+500 \mathrm{mM} \mathrm{NaCl}$, twice with buffer III (10 mM Tris-HCl, pH 8.0, 1 mM EDTA, $250 \mathrm{mM} \mathrm{LiCl,} 1 \% \mathrm{NP}-40,1 \%$ sodium deoxycholate) and once with TE buffer (10 mM Tris-HCl pH 8.0, $1 \mathrm{mM}$ EDTA). The immunoprecipitated material was eluted from the beads by two sequential incubations in $100 \mu \mathrm{l}$ of buffer B (50 mM Tris- $\mathrm{HCl}, \mathrm{pH} 7.5,1 \% \mathrm{SDS}, 10 \mathrm{mM} \mathrm{EDTA})$ at $65^{\circ} \mathrm{C}$ during $8 \mathrm{~min}$. Proteinase K (Roth) was added to the eluted material and to input ( $10 \%$ of total IP volume set aside before antibody addition) to a final concentration $0.75 \mathrm{mg} / \mathrm{ml}$ and incubated at $42^{\circ} \mathrm{C}$ for $2 \mathrm{~h}$. De-crosslinking was done at $65^{\circ} \mathrm{C}$ for $15 \mathrm{~h}$ followed by DNA purification by Wizard ${ }^{\circledR}$ SV Gel and PCR Clean-Up System (Promega). Quantification of total or precipitated DNA was done by RT-qPCR using SYBR ${ }^{\circledR}$ Green PCR Master Mix kit (Applied Biosystems) and primers listed in Table S2. Percentage of input for different regions was normalized to intergenic region 2 on the right arm of chromosome $\mathrm{IV}^{42}$.

Western blot analysis. For checking the expression level of Pol $\eta, 50 \mathrm{ml}$ yeast cultures grown in YPD were harvested at $\mathrm{A}_{600}$ : 1.0. Whole cell extracts were prepared by a glass-bead lysis method in $1 \times \mathrm{PBS}(137 \mathrm{mM} \mathrm{NaCl}$, $2.7 \mathrm{mM} \mathrm{KCl}, 10 \mathrm{mM} \mathrm{Na}_{2} \mathrm{HPO}_{4}, 10 \mathrm{mM} \mathrm{KH}_{2} \mathrm{PO}_{4} .1 \mathrm{mM}$ EDTA, $10 \%$ glycerol) with protease inhibitors. Cell lysates were quantified by Bradford. Equal amounts of whole cell lysates were separated by SDS-PAGE and analyzed by Western blotting using anti-Rad30 (sc-11868 Santa Cruz) and anti-PGK (Invitrogen A6457) primary antibodies, and anti-goat (sc-2020 Santa Cruz) and anti-mouse (Thermo Scientific 31430) secondary antibodies.

Statistical analysis. Student's t-test using Excel (Microsoft, Redmond, WA, USA) was applied to compare separate groups. p-values of $<0.05$ were considered statistically significant.

Data availability. All data generated or analyzed during this study are included in this published article (and its Supplementary Information files).

\section{References}

1. Prakash, S., Johnson, R. E. \& Prakash, L. Eukaryotic translesion synthesis DNA polymerases: specificity of structure and function. Annu Rev Biochem 74, 317-353, https://doi.org/10.1146/annurev.biochem.74.082803.133250 (2005).

2. Johnson, R. E., Prakash, S. \& Prakash, L. Efficient bypass of a thymine-thymine dimer by yeast DNA polymerase, Poleta. Science 283, 1001-1004 (1999).

3. Trincao, J. et al. Structure of the catalytic core of S. cerevisiae DNA polymerase eta: implications for translesion DNA synthesis. Mol Cell 8, 417-426, doi:S1097-2765(01)00306-9 (2001).

4. Haracska, L., Yu, S. L., Johnson, R. E., Prakash, L. \& Prakash, S. Efficient and accurate replication in the presence of 7,8-dihydro-8oxoguanine by DNA polymerase eta. Nat Genet 25, 458-461, https://doi.org/10.1038/78169 (2000).

5. McDonald, J. P., Levine, A. S. \& Woodgate, R. The Saccharomyces cerevisiae RAD30 gene, a homologue of Escherichia coli dinB and umuC, is DNA damage inducible and functions in a novel error-free postreplication repair mechanism. Genetics 147, 1557-1568 (1997).

6. Choi, J. H. \& Pfeifer, G. P. The role of DNA polymerase eta in UV mutational spectra. DNA Repair (Amst) 4, 211-220, doi:S15687864(04)00285-X (2005).

7. Busuttil, R. A., Lin, Q., Stambrook, P. J., Kucherlapati, R. \& Vijg, J. Mutation frequencies and spectra in DNA polymerase etadeficient mice. Cancer Res 68, 2081-2084, https://doi.org/10.1158/0008-5472.CAN-07-6274 68/7/2081 (2008).

8. Masutani, C. et al. The XPV (xeroderma pigmentosum variant) gene encodes human DNA polymerase eta. Nature 399, 700-704, https://doi.org/10.1038/21447 (1999).

9. Johnson, R. E., Kondratick, C. M., Prakash, S. \& Prakash, L. hRAD30 mutations in the variant form of xeroderma pigmentosum. Science 285, 263-265, doi:7658 (1999).

10. Washington, M. T., Johnson, R. E., Prakash, S. \& Prakash, L. Fidelity and processivity of Saccharomyces cerevisiae DNA polymerase eta. J Biol Chem 274, 36835-36838 (1999).

11. Haracska, L., Kondratick, C. M., Unk, I., Prakash, S. \& Prakash, L. Interaction with PCNA is essential for yeast DNA polymerase eta function. Mol Cell 8, 407-415, doi:S1097-2765(01)00319-7 (2001).

12. Haracska, L. et al. Physical and functional interactions of human DNA polymerase eta with PCNA. Mol Cell Biol 21, 7199-7206, https://doi.org/10.1128/MCB.21.21.7199 (2001).

13. Gao, G. X., Orlova, M., Georgiadis, M. M., Hendrickson, W. A. \& Goff, S. P. Conferring RNA polymerase activity to a DNA polymerase: A single residue in reverse transcriptase controls substrate selection. P Natl Acad Sci USA 94, 407-411, https://doi. org/10.1073/pnas.94.2.407 (1997).

14. Astatke, M., Ng, K. M., Grindley, N. D. F. \& Joyce, C. M. A single side chain prevents Escherichia coli DNA polymerase I (Klenow fragment) from incorporating ribonucleotides. P Natl Acad Sci USA 95, 3402-3407, https://doi.org/10.1073/pnas.95.7.3402 (1998).

15. Patel, P. H. \& Loeb, L. A. Multiple amino acid substitutions allow DNA polymerases to synthesize RNA. Journal of Biological Chemistry 275, 40266-40272, https://doi.org/10.1074/jbc.M005757200 (2000).

16. Nick McElhinny, S. A. et al. Abundant ribonucleotide incorporation into DNA by yeast replicative polymerases. Proc Natl Acad Sci USA 107, 4949-4954, https://doi.org/10.1073/pnas.0914857107 (2010).

17. Clausen, A. R., Zhang, S., Burgers, P. M., Lee, M. Y. \& Kunkel, T. A. Ribonucleotide incorporation, proofreading and bypass by human DNA polymerase delta. DNA Repair. 12, 121-127 (2013).

18. Goksenin, A. Y. et al. Human DNA Polymerase epsilon Is Able to Efficiently Extend from Multiple Consecutive Ribonucleotides. Journal of Biological Chemistry 287, 42675-42684 (2012).

19. Lazzaro, F. et al. RNase H and Postreplication Repair Protect Cells from Ribonucleotides Incorporated in DNA. Molecular Cell 45, 99-110 (2012).

20. Donigan, K. A. et al. Unlocking the steric gate of DNA polymerase eta leads to increased genomic instability in Saccharomyces cerevisiae. DNA Repair 35, 1-12, https://doi.org/10.1016/j.dnarep.2015.07.002 (2015).

21. McElhinny, S. A. N. et al. Genome instability due to ribonucleotide incorporation into DNA. Nature Chemical Biology 6, 774-781 (2010). 
22. Eder, P. S., Walder, R. Y. \& Walder, J. A. Substrate-Specificity of Human Rnase-H1 and Its Role in Excision Repair of Ribose Residues Misincorporated in DNA. Biochimie 75, 123-126 (1993).

23. McCulloch, S. D. et al. Preferential cis-syn thymine dimer bypass by DNA polymerase $\eta$ occurs with biased fidelity. Nature 428, 97-100, https://doi.org/10.1038/nature02352 (2004).

24. Exinger, F. \& Lacroute, F. 6-Azauracil inhibition of GTP biosynthesis in Saccharomyces cerevisiae. Curr Genet 22, 9-11 (1992).

25. Archambault, J., Lacroute, F., Ruet, A. \& Friesen, J. D. Genetic interaction between transcription elongation factor TFIIS and RNA polymerase II. Mol Cell Biol 12, 4142-4152 (1992).

26. Shaw, R. J., Wilson, J. L., Smith, K. T. \& Reines, D. Regulation of an IMP dehydrogenase gene and its overexpression in drug-sensitive transcription elongation mutants of yeast. J Biol Chem 276, 32905-32916, https://doi.org/10.1074/jbc.M105075200 (2001).

27. Hampsey, M. Molecular genetics of the RNA polymerase II general transcriptional machinery. Microbiol Mol Biol Rev 62, 465-503 (1998).

28. Wind, M. \& Reines, D. Transcription elongation factor SII. Bioessays 22, 327-336, https://doi.org/10.1002/(SICI) 1521-1878(200004)22:4<327::AID-BIES3>3.0.CO;2-4 (2000)

29. Woychik, N. A., Lane, W. S. \& Young, R. A. Yeast RNA polymerase II subunit RPB9 is essential for growth at temperature extremes. J Biol Chem 266, 19053-19055 (1991)

30. Laurent, B. C., Treitel, M. A. \& Carlson, M. The SNF5 protein of Saccharomyces cerevisiae is a glutamine- and proline-rich transcriptional activator that affects expression of a broad spectrum of genes. Mol Cell Biol 10, 5616-5625 (1990).

31. Reines, D. Use of RNA yeast polymerase II mutants in studying transcription elongation. Methods Enzymol 371, 284-292, https:// doi.org/10.1016/S0076-6879(03)71021-0 S0076687903710210 (2003).

32. Riles, L., Shaw, R. J., Johnston, M. \& Reines, D. Large-scale screening of yeast mutants for sensitivity to the IMP dehydrogenase inhibitor 6-azauracil. Yeast 21, 241-248, https://doi.org/10.1002/yea.1068 (2004).

33. Gibney, P. A., Fries, T., Bailer, S. M. \& Morano, K. A. Rtr1 is the Saccharomyces cerevisiae homolog of a novel family of RNA polymerase II-binding proteins. Eukaryot Cell 7, 938-948, https://doi.org/10.1128/Ec.00042-08 (2008).

34. Kaplan, C. D., Holland, M. J. \& Winston, F. Interaction between transcription elongation factors and mRNA $3^{\prime}$-end formation at the Saccharomyces cerevisiae GAL10-GAL7 locus. Journal of Biological Chemistry 280, 913-922, https://doi.org/10.1074/jbc. M411108200 (2005).

35. Vaudano, E., Noti, O., Costantini, A. \& Garcia-Moruno, E. Identification of reference genes suitable for normalization of RT-qPCR expression data in Saccharomyces cerevisiae during alcoholic fermentation. Biotechnology Letters 33, 1593-1599, https://doi. org/10.1007/s10529-011-0603-y (2011).

36. Lee, S. K., Yu, S. L., Prakash, L. \& Prakash, S. Requirement for yeast RAD26, a homolog of the human CSB gene, in elongation by RNA polymerase II. Molecular and Cellular Biology 21, 8651-8656, https://doi.org/10.1128/Mcb.21.24.8651-8656.2001 (2001).

37. Ogi, T. \& Lehmann, A. R. The Y-family DNA polymerase kappa (pol kappa) functions in mammalian nucleotide-excision repair. Nat Cell Biol 8, 640-642, doi:ncb1417 (2006).

38. Sarkar, S., Davies, A. A., Ulrich, H. D. \& McHugh, P. J. DNA interstrand crosslink repair during G1 involves nucleotide excision repair and DNA polymerase zeta. EMBO J 25, 1285-1294, doi:7600993 (2006).

39. Cohen, S. E., Godoy, V. G. \& Walker, G. C. Transcriptional modulator NusA interacts with translesion DNA polymerases in Escherichia coli. J Bacteriol 191, 665-672, https://doi.org/10.1128/JB.00941-08 JB.00941-08 (2009).

40. Tous, C. et al. A novel assay identifies transcript elongation roles for the Nup84 complex and RNA processing factors. EMBO J 30, 1953-1964, https://doi.org/10.1038/emboj.2011.109 emboj2011109 (2011).

41. Millan-Zambrano, G. et al. The prefoldin complex regulates chromatin dynamics during transcription elongation. PLoS Genet $\mathbf{9}$, e1003776, https://doi.org/10.1371/journal.pgen.1003776 PGENETICS-D-13-00163 (2013).

42. Zenklusen, D., Vinciguerra, P., Wyss, J. C. \& Stutz, F. Stable mRNP formation and export require cotranscriptional recruitment of the mRNA export factors Yralp and Sub2p by Hprlp. Mol Cell Biol 22, 8241-8253 (2002).

43. Kondratick, C. M., Washington, M. T., Prakash, S. \& Prakash, L. Acidic residues critical for the activity and biological function of yeast DNA polymerase eta. Mol Cell Biol 21, 2018-2025, https://doi.org/10.1128/MCB.21.6.2018-2025.2001 (2001).

44. Zhou, W. \& Doetsch, P. W. Effects of abasic sites and DNA single-strand breaks on prokaryotic RNA polymerases. Proc Natl Acad Sci USA 90, 6601-6605 (1993).

45. Liu, J., Zhou, W. \& Doetsch, P. W. RNA polymerase bypass at sites of dihydrouracil: implications for transcriptional mutagenesis. Mol Cell Biol 15, 6729-6735 (1995).

46. Viswanathan, A. \& Doetsch, P. W. Effects of nonbulky DNA base damages on Escherichia coli RNA polymerase-mediated elongation and promoter clearance. J Biol Chem 273, 21276-21281 (1998).

47. Pieper, R. O., Futscher, B. W. \& Erickson, L. C. Transcription-terminating lesions induced by bifunctional alkylating agents in vitro. Carcinogenesis 10, 1307-1314 (1989).

48. Cullinane, C. \& Phillips, D. R. In vitro transcription analysis of DNA adducts induced by cyanomorpholinoadriamycin. Biochemistry 31, 9513-9519 (1992).

49. Thrall, B. D., Mann, D. B., Smerdon, M. J. \& Springer, D. L. DNA polymerase, RNA polymerase and exonuclease activities on a DNA sequence modified by benzo[a]pyrene diolepoxide. Carcinogenesis 13, 1529-1534 (1992).

50. Selby, C. P. \& Sancar, A. Transcription preferentially inhibits nucleotide excision repair of the template DNA strand in vitro. J Biol Chem 265, 21330-21336 (1990).

51. Doetsch, P. W. Translesion synthesis by RNA polymerases: occurrence and biological implications for transcriptional mutagenesis. Mutat Res 510, 131-140, doi:S0027510702002580 (2002).

52. Marietta, C. \& Brooks, P. J. Transcriptional bypass of bulky DNA lesions causes new mutant RNA transcripts in human cells. EMBO Rep 8, 388-393, doi:7400932 (2007).

53. Ljungman, M. \& Zhang, F. Blockage of RNA polymerase as a possible trigger for u.v. light-induced apoptosis. Oncogene 13, 823-831 (1996).

54. Charlet-Berguerand, N. et al. RNA polymerase II bypass of oxidative DNA damage is regulated by transcription elongation factors. EMBO J 25, 5481-5491, doi:7601403 (2006).

55. Lindqvist, M. S. M., Winqvist, A., Rozners, E., Strömberg, R. \& Graslund, A. Optical spectroscopic study of the effects of a single deoxyribose substitution in a ribose backbone: implications in RNA-RNA interactions. Biochemistry 39, 1693-1701 (2000).

56. Bahadur, R. P. Z. M. \& Janin, J. Dissecting protein-RNA recognition sites. Nucleic Acids Res 36, 2705-2716 (2008).

57. Doudna, J. A. C. J. H. RNA structure: Crystal clear? Current Opinion in Structural Biology 7, 310-316 (1997).

58. Komissarova, N. \& Kashlev, M. RNA polymerase switches between inactivated and activated states By translocating back and forth along the DNA and the RNA. J Biol Chem 272, 15329-15338 (1997).

59. Nudler, E., Mustaev, A., Lukhtanov, E. \& Goldfarb, A. The RNA-DNA hybrid maintains the register of transcription by preventing backtracking of RNA polymerase. Cell 89, 33-41, S0092-8674(00)80180-4 (1997).

60. Bar-Nahum, G. et al. A ratchet mechanism of transcription elongation and its control. Cell 120, 183-193, doi:S0092867404011493 (2005).

61. Soria, G. et al. DNA damage induced Pol eta recruitment takes place independently of the cell cycle phase. Cell Cycle 8, 3340-3348, doi:9836 (2009)

62. Jackson, D. A.. Hassan, A. B., Errington, R. J. \& Cook, P. R. Visualization of focal sites of transcription within human nuclei. $E M B O$ $J$ 12, 1059-1065 (1993). 
63. Wansink, D. G. et al. Fluorescent labeling of nascent RNA reveals transcription by RNA polymerase II in domains scattered throughout the nucleus. J Cell Biol 122, 283-293 (1993).

64. Iborra, F. J., Pombo, A., Jackson, D. A. \& Cook, P. R. Active RNA polymerases are localized within discrete transcription "factories' in human nuclei. J Cell Sci 109(Pt 6), 1427-1436 (1996).

65. Su, Y., Egli, M. \& Guengerich, F. P. Mechanism of Ribonucleotide Incorporation by Human DNA Polymerase eta. Journal of Biological Chemistry 291, 3747-3756, https://doi.org/10.1074/jbc.M115.706226 (2016).

66. Mentegari, E. C. E. et al. Ribonucleotide incorporation by human DNA polymerase $\eta$ impacts translesion synthesis and RNase H2 activity. Nucleic Acids Res (2016).

67. Knop, M. et al. Epitope tagging of yeast genes using a PCR-based strategy: more tags and improved practical routines. Yeast 15, 963-972, https://doi.org/10.1002/(SICI) 1097-0061 (1999).

68. Johnson, R. E., Prakash, L. \& Prakash, S. Yeast and human translesion DNA synthesis polymerases: expression, purification, and biochemical characterization. Methods Enzymol 408, 390-407, doi:S0076-6879(06)08024-4 (2006).

69. Cornish-Bowden, A. Principles of Enzyme kinetics. (2004).

70. McNabb, D. S., Reed, R. \& Marciniak, R. A. Dual luciferase assay system for rapid assessment of gene expression in Saccharomyces cerevisiae. Eukaryot Cell 4, 1539-1549, doi:4/9/1539 (2005).

71. Shaw, R. J. \& Reines, D. Saccharomyces cerevisiae transcription elongation mutants are defective in PUR5 induction in response to nucleotide depletion. Mol Cell Biol 20, 7427-7437 (2000).

72. Steinmetz, E. J. \& Brow, D. A. Ssu72 protein mediates both poly(A)-coupled and poly(A)-independent termination of RNA polymerase II transcription. Mol Cell Biol 23, 6339-6349 (2003).

\section{Acknowledgements}

We thank Andres Aguilera for providing the pCYC-LacZ plasmid for the GLRO experiments, and Szilvia Minorits for technical assistance. This work was also supported by grants from the National Research, Development and Innovation Office: GINOP-2.3.2-15-2016-00001 and GINOP-2.3.2-15-2016-00024.

\section{Author Contributions}

Designed the experiments: V.K.G., E.B., N.S., F.S., I.U. Performed the experiments: V.K.G., E.B., N.S., O.F., I.U. Analyzed the data: V.K.G., E.B., N.S., F.S., I.U. Conceived and designed the project and wrote the manuscript: I.U. Edited the manuscript: V.K.G., E.B., N.S., F.S.

\section{Additional Information}

Supplementary information accompanies this paper at https://doi.org/10.1038/s41598-017-12915-1.

Competing Interests: The authors declare that they have no competing interests.

Publisher's note: Springer Nature remains neutral with regard to jurisdictional claims in published maps and institutional affiliations.

(c) (i) Open Access This article is licensed under a Creative Commons Attribution 4.0 International License, which permits use, sharing, adaptation, distribution and reproduction in any medium or format, as long as you give appropriate credit to the original author(s) and the source, provide a link to the Creative Commons license, and indicate if changes were made. The images or other third party material in this article are included in the article's Creative Commons license, unless indicated otherwise in a credit line to the material. If material is not included in the article's Creative Commons license and your intended use is not permitted by statutory regulation or exceeds the permitted use, you will need to obtain permission directly from the copyright holder. To view a copy of this license, visit http://creativecommons.org/licenses/by/4.0/.

(C) The Author(s) 2017 